\title{
Measurement of Corporate Social Responsibility: A Review of Corporate Sustainability Indexes, Rankings and Ratings
}

\author{
Borja Diez-Cañamero ${ }^{1, *}$, Tania Bishara ${ }^{1}$, Jose Ramon Otegi-Olaso ${ }^{1}\left(\mathbb{D}\right.$, Rikardo Minguez $^{1}{ }^{(}$and \\ José María Fernández ${ }^{2}$ \\ 1 Department of Graphic Design and Engineering Projects, Faculty of Engineering, \\ University of the Basque Country (UPV/EHU), 48013 Bilbao, Spain; taniabishara@gmail.com (T.B.); \\ joserra.otegi@ehu.eus (J.R.O.-O.); rikardo.minguez@ehu.eus (R.M.) \\ 2 IHOBE, Basque Government, 48011 Bilbao, Spain; jose_maria.fernandez@ihobe.eus \\ * Correspondence: bdiez004@ikasle.ehu.eus
}

Received: 21 February 2020; Accepted: 6 March 2020; Published: 10 March 2020 updates

\begin{abstract}
Companies are currently changing their traditional role in society and transforming it into a proactive role in which their operations generate social and environmental positive impacts. Corporate Social Responsibility (CSR) has evolved from simple philanthropy to a more theoretical concept with a new corporate philosophy that takes all the interests of all stakeholders into consideration. The financial market is pushing the development of Socially Responsible Investment (SRI), which has led to the rise of Corporate Sustainability Systems (CSS). These CSSs are tools that rate corporate performance on sustainability. However, they constitute a chaotic universe, with instruments of different nature. This paper identifies and groups the common characteristics of the CSSs into three different typologies: Indexes, Rankings and Ratings. Despite this classification, and although the fundamental pillar of CSR is the "Stakeholder Theory", CSSs are still not ideal tools to be used by all stakeholders. From the magma of CSSs, this article identifies and describes, through a comparative analysis, those which best comply with the "Stakeholder Theory". This paper facilitates the work of researchers and stakeholders by exposing the differential characteristics of the most important CSSs.
\end{abstract}

Keywords: Corporate Social Responsibility (CSR); Socially Responsible Investment (SRI); Environment, Social and Governance Criterion (ESG); Stakeholder Theory; sustainability Indexes; sustainability Rankings; sustainability Ratings; ESG performance; sustainability performance; corporate sustainable system

\section{Introduction}

The new millennium brought the 10 Principles of the United Nations (UN) Global Compact. These principles constitute an important roadmap for companies wishing to align their corporate practices with sustainable development [1]. In order to approach corporate sustainability, this Global Compact has become a major voluntary initiative. This document presents a global and holistic view, called Corporate Social Responsibility (CSR), which has served as a foundation for subsequent initiatives destined at promoting a more sustainable and responsible private sector [2].

Simultaneously, the UN approved the Millennium Development Goals (MDG) in 2000. These goals corroborate that sustainable development is not just a passing fad. On the contrary, it is a concept that has come to regulate any human activity, regardless of its scale and nature. However, and despite their good intentions, the MDGs have proven insufficient and have become obsolete. In 2015, framed within the 2030 Agenda, the 17 Sustainable Development Goals (SDG) were presented. These SDGs 
are the heirs of the MDGs, but their scope is much broader because they take into consideration new areas such as/they present a broader scope and introduce new areas such as climate change, economic inequality, innovation, sustainable consumption and peace and justice [3]. These goals are the result of the consensus of 193 UN Member States and several stakeholders have been involved in its elaboration. The SDGs are a universal and inclusive call, and they are interrelated in such a way that they can be implemented in all countries, independently of their reality, needs and characteristics [4]. In order to monitor and revise the implementation of these goals, 169 targets and 230 specific and clear indicators have been established.

A thorough analysis of these SDGs shows that they constitute a true social engagement to achieve worldwide sustainable development in their three dimensions: economic, social and environmental. The document presents these goals in a balanced, global and integral way, involving all stakeholders: governments, business sector, civil society and citizens. However, several years after its adoption, the 2030 Agenda has revealed a number of structural flaws [5]. One of the most notorious flaws is that the targets and indicators developed to monitor the implementation of these SDGs have a macro approach which makes their application at enterprise level difficult. Due to this macro approach, companies find it difficult to evaluate and measure their real contribution to the SDGs.

Then, if the indicators of a tool that is designed to be used by all stakeholders and has the recognition of all international social actors do not objectively evaluate the contribution of companies to sustainable development, how can a company know the extent to which its performance is responsible from the point of view of sustainable development?

At present, companies answer this question using the Indexes, Rankings and Ratings that measure the corporate performance in sustainability [6-14]. These three elements shape the Corporate Sustainability Systems (CSS) universe. This article uses the CSSs to analyze, evaluate and measure, both qualitatively and quantitatively, the sustainability of the most important companies worldwide. CSSs' results are expressed in Environment, Social and Governance (ESG) terms and they follow a CSR approach. In addition, the CSSs use their own methodology reviewed by an independent third party.

Since the birth of the UN Global Compact, the business of ESG rating agencies has evolved through mergers and acquisitions [15]. Likewise, the number of stock market operators that manage indices that measure corporate sustainability has grown considerably [16], especially in developed markets. This has resulted in a vast and chaotic universe of products that qualify companies in ESG terms, with an offer that encompasses global or regional CSSs, CSSs focused on a specific activity sector or whose evaluation process is multi-sectorial, or CSSs that address ESG terms globally or focus on a sustainability specific aspect.

The concept of CSR has evolved taking Freeman's "Stakeholder Theory" of 1984 [17] as a starting point. This theory states that any tool that can be used by a company internally and that serves to improve the sustainability, must have a multi-stakeholder approach. Accordingly, the tools used to measure ESG performance should comply with this theory.

However, CSSs are highly focused on the financial market. This means that, in order to satisfy the interests of shareholders and socially responsible investors, CSSs have a high financial weight. Several aspects reflect this economic bias: the selection of the companies that will make up the universe of CSSs, the methodology selected to develop the CSSs, and the weight given to economic criteria in the evaluation processes of the CSSs. Consequently, the most used instruments to know how and to what measure a company is correctly implementing CSR in its corporate strategy only take into account a reduced spectrum of the global map of stakeholders.

Several problems have arisen in the CSSs' universe. A main problem is the heterogeneity of the evaluation processes. If all CSSs aim to measure the degree of CSR in a company, why do they use such a variety of methodologies? An immediate effect is the limited comparability between CSSs, a situation aggravated by the subjective information collected by the CSSs' managers necessary to carry out the evaluations [12]. Another problem is the compensation for negative scores, which calls in question the balance of the three ESG pillars when giving more weight to the economic aspect [6]. 
In this context, stakeholders will be confused when selecting the most adequate CSSs to satisfy their interests. Thus, the aim of this study is to put order in this chaotic universe by cataloguing the most important CSSs using a selection of criteria that allow their qualitative description at all levels: academic, business, global and multi-sectorial. To determine whether the CSSs comply with the "Stakeholder Theory", these criteria have followed a multi-stakeholder approach. A descriptive-comparative analysis of their common characteristics will be the basis to classify the CSSs into typological Blocks.

The results obtained will provide a new insight of the nature of the CSSs, different from previous works. Some research compares the general aspects and indicators used in the evaluation processes of the CSSs $[7,9,11,15,18-22]$. The main value of this new insight into the CSS's universe, which makes the difference between this and previous analyses, is its multi-stakeholder approach, which any CSR tool must have.

This article presents the following structure. Section 2 exposes the CSR conceptual evolution and identifies the main theories of its scientific development. The last part of this section exposes the literature related to the Indexes, Rating and Ranking that measure corporate sustainability and presents the theory framing this study. Then, Section 3 describes the methodology followed in this study. Afterwards, Section 4 presents a descriptive-comparative analysis of the CSSs and discusses the results of the research. The final section exposes the conclusions and limitations of the study and establishes future lines of research.

\section{Literature Review (Theoretical Background)}

Topics of current interest like climate change, the salary gap or social inequality are causing a change in the conception of relations between social actors. This new conception has resulted in a displacement of their interests and values towards social and environmental aspects. In 1987, the publication of the "Brundtland Report" by the UN World Commission on Environment and Development constituted an important milestone in the achievement of sustainable development. In this report, sustainable development is defined for the first time as the development that "meets the needs of the present without compromising the ability of future generations to meet their own needs" [23] (p. 24). This definition changed the conception of development from a mono-dimensional approach understood only as unlimited economic and material growth, to a multi-dimensional approach that emphasizes the depletion of natural resources and understands that economic growth must go hand in hand with social welfare and respect for the environment. Therefore, this report established the three pillars of sustainable development: economic sustainability, environmental sustainability and social sustainability. These pillars must guide all activities carried out by governments, communities, companies, citizens and society in general; any initiative aiming to promote sustainable development must take them into account [24]. Sustainability arises from the balance of these pillars [25].

A paradigm change has also occurred in the private sector. This change questions the traditional business logic. Within the capitalist context impregnating the markets, the "Shareholder Theory" or "Stockholder Theory" has historically guided corporate performance. For Friedman, "there is one and only one social responsibility of business-to use its resources and engage in activities designed to increase its profits so long as it stays within the rules of the game, which is to say, engages in open and free competition, without deception of fraud" [26] (p. 133). Consequently, according to this conception, the companies' ultimate aim is to maximize the shareholders' wealth and all financial decisions will only have this goal in mind [27].

In 1986, Freeman cited the "Stakeholder Theory" for the first time, presenting as a new conception of corporate responsibility, opposed largely to the classic vision. Freeman defines the stakeholder as "any group or individual who can affect or is affected by the achievement of an organization's purpose" [17] (p. 53). This theory establishes that by introducing the stakeholders' demands, interests, expectations and needs into the company's decision-making, the relations between the management and the stakeholders will generate an intangible that will increase the company's results and contribute benefits to society, constituting a value shared by all stakeholders [28]. 
A comparison of the two conceptual frameworks shows that they differ in three specific aspects. The "Shareholder Theory" emphasizes the maximization of short-term revenue, even tolerating a certain degree of stakeholders' exploitation [27]. On the other hand, the "Stakeholder Theory" determines that companies should aim at a maximum long-term benefit in the three aspects of sustainability, always in favor of all stakeholders. Therefore, Freeman does not deny that the search of economic profitability is a legitimate goal of companies [29], but it is not the ultimate goal. It must be a vehicle to improve the interests of stakeholders and to create shared value to all stakeholders [30].

The Triple Bottom Line (TBL), coined by Elkington, emerged at the beginning of the 21st century. This concept helps companies to clarify their way to sustainable business. Perfectly aligned with previous concepts, the TBL was born to place itself at the core of the companies' strategies, focusing on the corporate performance and results measured in economic, environmental and social terms. When referring to TBL, Elkington's view is that "Future market success will often depend on an individual company's (or entire value chain's) ability to simultaneously satisfy not just the traditional bottom line of profitability but also two emergent bottom lines; one focusing on environmental quality, the other on social justice. As a result, companies and their boards will need to think in terms of the triple bottom line" [31] (p. XI). Likewise, The Economist mentions that "Companies with an eye on their triple bottom line-economical, environmental, and social sustainability—outperform their less fastidious peers on the stock market" [32] (p. 149).

Thanks to the emergence of these conceptual frameworks, as well as to society's growing concern about environmental and social issues, the companies implemented CSR initiatives within the business practices. Their main goal was to ensure that corporate operations and activities are sustainable, i.e., that these activities are carried out to generate the maximum benefit for society, causing the least negative impact, without endangering the options and needs of future generations [31].

The CSR definition has been widely addressed in the scientific literature [33]. Bowen, one of the fathers of CSR, defines CSR from the businessperson's point of view [34], whose responsibility is to align all decisions and actions with the objectives and values of society [35]. Bowen links CSR directly with the managers' social conscience, and not with the company's general actions. Frederick, another CSR father, goes one step further and links CSR to the satisfaction of the expectations of the public and society in general, so CSR is not subordinated to the companies' interests [36]. McGuire goes beyond Frederick's description by defining CSR as responsibilities that go beyond legal obligations [37]. Walton approaches CSR as a business-society relationship, necessary to meet their objectives [38].

At this point of the game, the CSR already adopts a multi-stakeholder perspective converging with the "Stakeholder Theory". Thus, Freeman further adjusts the definition of CSR, and he specifies and details the stakeholders that the companies must manage and the interests must satisfy to align the corporate processes with sustainable development. Specifically, Freeman establishes a map of 11 stakeholders that are in the company's orbit [17].

At the institutional level, several international organizations have established definitions of CSR [33]. The European Commission (EC) states CSR is a "concept whereby companies integrate social and environmental concerns in their business operations and in their interaction with their stakeholders on a voluntary basis; being socially responsible means not only fulfilling legal expectations, but also going beyond compliance and investing "more" into human capital, the environment and the relations with stakeholders" [39] (p. 6). The International Organization for Standardization (ISO) defines CSR as the "responsibility of an organization for the impacts of its decisions and activities on society and the environment, through transparent and ethical behavior that: contributes to sustainable development, including health and the welfare of society; takes into account the expectations of stakeholders; is in compliance with applicable law and consistent with international norms of behavior; and is integrated throughout the organization and practiced in its relationships" [40] (p. 3). Finally, for the World Business Council for Sustainable Development (WBCSD), CSR is a "business commitment to contribute to sustainable economic development, working with their employees, their families, the local community and society at large to improve their quality of life" [41]. 
These non-academic definitions of CSR also give a determining role to stakeholders. The EC grants a passive attitude to stakeholders. However, the ISO and WBCSD give a greater prominent role to stakeholders. The ISO considers that the stakeholders' interests should be taken into account to establish corporate strategies and in decision-making. Although in this case, stakeholders have a more prominent role, they are still considered agents outside the companies' orbit. The WBCSD claims that companies should work together with stakeholders for sustainable development, and puts the company and stakeholders on the same level.

Likewise, the CSR theoretical development has evolved according to the approach that companies adopt towards stakeholders, based on two central aspects: the participation of stakeholders in companies, and for whom and how wealth is created. The literature has used four different approaches to explain why the companies use CSR initiatives: "Regulation Approach", "Descriptive Approach", "Instrumental Approach" or "Strategic Approach" [42]. Therefore, the choice of one approach or another depends on the relationship with the stakeholders that companies want to achieve [43]. The "Regulation Approach" is justified from the companies' ethics. As primary social actors, companies have the moral obligation to act in the most responsible way, thus implementing CSR tools. Some authors consider this approach as an "Ethical Approach" [44]. From the "Descriptive Approach", any company operating on the CSR basis acquires a legitimacy that will help society approve the companies' actions. The "Instrumental Approach" argues that CSR is only an instrument that increases the corporate reputation and generates a competitive advantage that results in the creation of value and wealth for the company [44]. Although the three approaches have their own arguments, they can coexist [45]. "The Strategic Approach" combines these approaches and, in the company-society binomial, this approach considers CSR as a new tool that companies have to create shared [46].

Garriga and Melé analyze the CSR theories and add two new visions [44]. The first is the "Political Theory", which emphasizes the need for a responsible use of the companies' political power in society. The companies receive this power because they are major actors in society. The second approach, named "Integrative Theory", searches to satisfy social demands, expectations and needs.

It is also important to analyze the companies' responsibilities towards society. Carroll's Social Responsibility Categories model considers that companies have four responsibilities [47]. The first responsibility is the "Economic Responsibility": society expects companies to produce and sell the products and services they demand. If they do so, they will make a benefit. The second responsibility is the "Legal Responsibility": society expects companies to act within the legal framework. The third is the "Ethical Responsibility": society expects companies to act under ethical behavior beyond the law. The final responsibility is the so-called "Discretionary Responsibility": in addition to legal and ethical standards, society expects companies to perform social functions, like philanthropic activities that provide economic support to specific social programs. In further texts, this latter responsibility was renamed "Philanthropic Responsibility" in the pyramid model [48].

Carroll's model resembles a pyramid [41,48]: the "Economic Responsibility" is at the base, the "Legal Responsibility" and the "Ethical Responsibility" are at the intermediate steps, and the "Philanthropic Responsibility" is at the top. Therefore, a company should not face these four responsibilities in isolation and in sequence, but should assume them at the same time, which means that "Philanthropic Responsibility" will only be taken into consideration once the other 3 responsibilities have been exceeded. In Carroll's words, "the CSR firm should strive to make a profit, obey the law, be ethical, and be a good corporate citizen" [48].

Another important concept related to CSR is the "shared value" established by Kramer and Porter. This "shared value" concept establishes that companies' concern for social and environmental issues will generate positive social impact and create economic and social value for both the company and its stakeholders [49]. By contrast, Aakhus and Bzdak determine that the shared value is insufficient to define the relationship society-CSR, and it does not delve into what is social value [50].

Therefore, corporate sustainability, understood as a set of tools and instruments that companies can use to reduce, mitigate or eliminate their negative impact on society—or even to create positive 
social and environmental impacts—-has evolved greatly. Thus, the actions of companies will be justified by the creation of shared economic, social and environmental value [46] between all stakeholders [28], beyond legal terms and with the obligation to be accountable between all stakeholders and not only to shareholders [31]. In addition, transparency must be the basis for whatever corporation action, and the companies should consider the open participation of stakeholders in decision-making. That is to say, stakeholders are not only a beginning, but also a means and an end. Therefore, the way to manage the CSR is shaping the classic company models, from a financial model that assumes a strategic-instrumental CSR model as described in the "Shareholder Theory", to a pluralist business model that raises the stakeholders' status in an advanced CSR, closer to the "Stakeholder Theory" [51].

Having stated and developed the theoretical and conceptual bases of CSR, the next step is to determine how a company can measure its CSR performance and contribution level to sustainable development. One of the first social actors to respond to this question was the financial market with the launch and development of CSSs. Although the previous paragraphs show a CSR evolution to a vision in which shareholders and economic benefit are away from the company's sustainability central core, currently the major mobilizers of business sustainability are investors who want to create their investment portfolio with companies that have a better ESG performance. This is known as Socially Responsible Investment (SRI). In 2008, Sparkes established a definition of ethical investment: "Ethical investment is straightforward, and simply means an investment philosophy that combines ethical or environmental goals with financial ones" [52] (p. 22).

\section{Sustainability Indexes, Rankings and Ratings}

CSR has evolved from philanthropy [50] to a more complex concept. In the past, corporate performance was measured according to the amount donated to a specific social project. Nowadays, as a result from the interconnection of multiple social and environmental variables together with the complex relationships among stakeholders, there is a need for more complex tools to measure CSR. This has led to the rise of initiatives such as social accounting, sustainability reporting, performance indicators, environmental and social standards $[6,9,53]$ as well as ESG ratings provided by rating agencies. These ESG ratings, in the form of CSSs, constitute one of the most useful and direct instruments used by companies to show their contribution to sustainable development to their entire stakeholders' panel [54]. The sustainability reports and the corporate websites of listed companies are a proof of this situation. However, despite this positive evolution, the measuring of corporate sustainability must continue to grow and integrate more variables [31], keeping always in mind the continuous management motto pronounced by William Thomson Kelvin, a physicist and mathematician of the 19th century: "What is not defined cannot be measured. What is not measured cannot be improved. What is not improved is always degraded".

Originally, ESG ratings were developed to respond to the growing SRI demand. Despite their conceptual differences, ethical investment and SRI are often used as synonyms [55], but this research does not delve into them. The launch of the Principles Responsible Investment (PRI) was an important event that led to the development of the SRI. This PRI is an initiative promoted by the UN in 2006 and aimed to promote the consideration of environmental, social and governance issues [55] in investment policies [56] of companies, institutions and particular investors. By introducing ESG criteria into investment policies, the financial market has been a major driver of CSR, because now, ESG agencies are starting to give credibility to corporate sustainability ratings. In recent years, SRI has become one of the tools most linked to CSR transcending the sphere of financial markets.

As a result of this situation, the industrial field of ESG rating agencies has progressed significantly, considerably increasing the offer of companies that provide this service and tools offered by them [15]. Unfortunately, this heterogeneous and chaotic CSSs' universe has resulted in some problematic situations.

The first problematic situation is that, although CSSs have the objective of measuring, qualifying and quantifying the same thing, companies do not obtain the same results in all the CSSs in which they 
participate [57]. ESG rating agencies and sustainability index managers do promote the best corporate practices in favor of sustainable development, but they are not (Non-governmental Organizations) NGOs and they do not do it selflessly [6]. The proliferation of tools to measure corporate sustainability performance is parallel to the increase in social and environmental concerns of society. However, in the current market logic in which each of the participants aims to increase the demand for their products, the methodologies used in the rating processes answer to particular interests. This fact subtracts objectivity and impartiality to these tools and drives to a lack of credibility in the CSSs as ideal indicators to determine a company's corporate sustainability.

CSSs were born to meet an increasing demand by shareholders, investors, governments and companies, all of them increasingly aware of the importance of introducing ESG extra-financial variables to elaborate their investment portfolio. Traditionally, this portfolio was only based on financial criteria such as risk, profitability or liquidity. Therefore, this new investor type is not only interested in investing in companies with a favorable economic expectation. Modern investors also take into consideration the positive environmental and social impacts generated by the companies' operations and activities. A strong stock market nature and a focus on investors and shareholders [15] can result in an economic bias by prioritizing the economic variable over the other two variables of the ESG criteria when assessing the corporate performance of companies, thus contradicting the TBL philosophy.

In view of this situation, stakeholders face a dilemma when selecting the most adequate tool to evaluate the sustainability performance of the most important companies worldwide. This article presents a comparative analysis of the major CCSs with global coverage and a multi-stakeholder approach. This analysis has been possible thanks to the selection of those criteria that allow a multi-stakeholder approach, this is, an approach that goes beyond economic, financial or stock market characteristics that only are interesting to private or institutional investors. The ultimate aim of this study is to present CSSs not as tools at the service of shareholders exclusively, but as authentic corporate ESG indicators available for any stakeholder such as public institutions, consumers, suppliers, employees, company managers, academics or sustainability experts.

\section{Data and Methodology}

\subsection{Data}

All information and data appearing in the article correspond to the first half of 2019. They were obtained through three major sources. First, consultation of scientific articles. Second, web pages and documents provided by CSSs' managers (annual reports, factsheets and documents explaining the CSS methodology). And third, sustainability reports, annual reports and corporate websites of the major companies in the industrial sectors of telecommunications, utilities and wind turbine manufacturers.

\subsection{Methodology}

The study took place in three general stages. First, the determination of the CSSs that will conform the final research sample. A general search of CSSs, at the academic and business level was carried out via three different approaches:

1. Identification of the articles used by ESG rating agencies or CSSs in their research framework, as well as other CSSs susceptible to be selected [6-15,18-22,53,58-71].

2. Consultation of the report "Rate the Raters 2019: Expert Views on ESG Ratings" of the consulting firm SustAinability [72]. Since 2010, this think tank annually evaluates the quality and usefulness of corporate sustainability ratings (excluding ESG Rankings), through online surveys of 319 sustainability professionals from 60 countries in Africa, Asia, Europe, Latin America, North America and Oceania. The report evaluates the following CSSs: the Bloomberg ESG Disclosure/Performance Score; the CDP Climate, Water \& Forests Scores; the EcoVadis CSR Rating; the FTSE Russell's ESG Ratings; the ISS Quality Score; the ISS-Oekom Corporate Rating; the 
ISS (unspecified index)/ISS Ethix; the Morgan Stanley Capital International (MSCI) ESG Ratings; the RobecoSAM Corporate Sustainability Assessment; the Sustainalytics' ESG Risk Ratings; the Sustainalytics Company ESG Reports; the Thomson Reuters ESG (Performance) Scores; and, finally, the Vigeo Eiris Sustainability Rating.

3. Analysis of sustainability reports and annual reports (period of 2010-2018), as well as the analysis of the sustainability section of the websites of the major international companies from three industrial sectors with an important presence in CSSs: telecommunications, utilities and wind turbine manufacturers (see Table 1). Companies use these communication channels to disclose any relevant information about their presence and performance in the CSSs to their stakeholders [73].

Table 1. Companies whose sustainability reports and corporate websites have been reviewed.

\begin{tabular}{ll}
\hline Industry Sector & Companies \\
\hline \multirow{3}{*}{ Telecommunications } & Deutsche Telekom AG; Euskaltel S.A.; KT Corporation; Orange S.A.; \\
& Telecom Italia (TIM) S.p.A.; Telefónica S.A.; Telia Company AB; Verizon \\
& Wireless; and Vodafone Group plc. \\
& Acciona, S.A.; CEZ Group; E.on AG; Électricité de France (edf) S.A.; \\
Utilities & Energias de Portugal (edp), S.A.; Endesa S.A.; Enel S.p.A.; Engie SA; \\
& Naturgy Energy Group S.A.; Iberdrola, S.A.; RWE AG; and Vattenfall AB. \\
& General Electric Company; Xinjiang Goldwind Science Technology Co., \\
Wind turbine manufacturers & Ltd.; Nordex SE; Senvion, S.A.; Siemens Gamesa Renewable Energy, S.A.; \\
& Sinovel Wind Group Co., Ltd.; Suzlon Energy Ltd.; and Vestas Wind \\
& Systems A/S. \\
\hline
\end{tabular}

A large sample of CSSs was obtained through this process. In order to reduce this amount, a screening based on three criteria was carried out.

First, those CSSs that do not have a global ESG vision and whose methodology only evaluates one factor of the sustainable development such as climate change, water management or workers' diversity and inclusion, have not been considered. Then, the CSSs whose geographical scope is regional or national were eliminated. Finally, those CSSs focusing on a specific business sector were eliminated. The CSSs excluded in the study are: the CDP Climate, Water and Forests Scores (Climate, Water and Forests A List); the CDP's Supply Chain Program (Supplier Climate and Water A List, and the Supplier Engagement Leader Board); the Climate Change Program Spain edition (Climate A List Spain edition); the Newsweek Green Ranking-Global 100; the ET Carbon Rankings; the InfluenceMap's Organization and Relationship Scores; the merco Responsibility and Corporate Governance; the Thomson Reuters Diversity and Inclusion Index; the Thomson Reuters/S-Network Developed Markets (ex-US) ESG Best Practices Index; the Thomson Reuters/S-Network Europe ESG Best Practices Index; the Cleantech Index (CTIUS); the Good Company Ranking-CSR (developed by Mazars and Kirchhoff consultants with companies of Germany's DAX 30 Index); the Bloomberg Gender-Equality Index (GHG); the World's Most Ethical Companies; the Business Sustainability Index (managed by BM\&FBOVESPA, Sao Paolo stock exchange, and the Brazilian Environment Ministry); the IndexAmericas (created by Inter-American Development Bank and S-Network Global Indexes); The Times Top 50 Employers for Women (company selection by Business in the Community); the top 100 Green Utilities of Energy Intelligence; or the FTSE4Good IBEX.

The final study sample has 15 CSSs: the Dow Jones Sustainability Index (DJSI) World; the ECPI World ESG Equity Index; the Ethibel Sustainability Index (ESI) Excellence Global; the Euronext Vigeo Eiris World 120; the FTSE4Good Developed Index; the Global Challenges Index (GCX); the Global CR RepTrak 100; the Global Sustainability Leaders Index (GSLI); the ISS-oekom Corporate Rating; the MSCI World ESG Leaders Index; the STOXX Global ESG Leaders Index; the Supplier CSR Rating; the Sustainalytics' ESG Risk Rating; The Sustainability Yearbook; and, finally, the World's Most Sustainable Corporations-Global 100. The sample is a varied selection of CSSs covering a large number of financial and capital markets (see Table A1). 
The second stage determined the criteria used to characterize the CSSs, by revising the last documents provided by the CSSs' managers [74-112]. The criteria that best describe the CSSs from a multi-stakeholder perspective were identified. Subsequently, these criteria were grouped into 5 thematic Blocks: "Block 1: General information about the CSSs" (see Table A1); "Block 2: Economic, financial and stock market criteria used to elaborate the CSSs" (see Table A2); "Block 3: Methodological criteria used by the managers to elaborate the CSSs" (see Table A3); "Block 4: Criteria for describing the companies sample that constitute the Initial Universe and the Final Universe of the CSSs" (see Table A4); and "Block 5: Criteria that allow stakeholders to know the public information provided by the CSSs' managers" (see Table A5).

Finally, in the last stage, the CSSs were grouped into three groups according to their nature: Index, Ranking and Rating. Furthermore, the criteria selected in the previous stage helped to identify and associate the characteristics that are common to each of the groups (see Table 7). In addition, the target stakeholder for each CSS was determined.

\section{Results}

This chapter presents the results of the comparative study.

First of all, by performing a comparative analysis, based on the five criteria Blocks approach, it has been possible to identify the CSSs' common characteristics and form affinity patterns to allow the division of the CSSs into three major groups: Indexes, Rankings and Ratings (see Table 7). These groups coincide with previous research [8,9]. The first group (Indexes) includes the DJSI World, the ECPI World ESG Equity Index, the ESI Excellence Global, the Euronext Vigeo Eiris World 120, the FTSE4Good Developed Index, the CGX, the GSLI, the MSCI World ESG Leaders Index, the STOXX Global ESG Leaders Index and the Sustainalytics' ESG Risk Rating. The second group (Rankings) is composed by the Global CR RepTrak 100, The Sustainability Yearbook and the World's Most Sustainable Corporations-Global 100. Finally, the third group (Ratings) is integrated by the ISS-oekom Corporate Rating and the Supplier CSR Rating.

The "Block 1: General information about the CSSs" (see Table A1) identifies and analyzes the following CSS variables (see Table 2):

Table 2. Variables by Corporate Sustainability Systems (CSS) included in the Block 1.

\begin{tabular}{|c|c|}
\hline Variable & Explanation \\
\hline (1) Launch Year. & Year when the CSS was created. \\
\hline (2) CSSs' Managers. & $\begin{array}{l}\text { CSSs' managers are named and described (with type of activity and } \\
\text { country of origin). }\end{array}$ \\
\hline (3) Generally accepted in science. & $\begin{array}{l}\text { Differentiates those CSSs which are mentioned in more than one } \\
\text { scientific paper. }\end{array}$ \\
\hline (4) Mentioned by companies. & $\begin{array}{l}\text { Differentiates those CSSs which are mentioned by international } \\
\text { companies from these three industrial sectors: telecommunications, } \\
\text { utilities and wind turbine manufacturers. }\end{array}$ \\
\hline (5) Appears under Rate the Raters. & $\begin{array}{l}\text { Differentiates those CSSs which are mentioned in the report "Rate the } \\
\text { Raters 2019: Expert Views on ESG Ratings" of SustainAbility [72]. }\end{array}$ \\
\hline (6) Evaluation theme. & $\begin{array}{l}\text { Sustainable development issues evaluated in each CSS (ESG, CSR, } \\
\text { Sustainability and/or SDGs). }\end{array}$ \\
\hline (7) Geographical scope. & Coverage of the countries of origin of the companies evaluated. \\
\hline (8) Sector approach. & $\begin{array}{l}\text { Differentiates those CSSs that evaluate a specific activity sector or those } \\
\text { CSSs that evaluate companies regardless of their industrial sector. }\end{array}$ \\
\hline
\end{tabular}

Except for the ISS-oekom Corporate Rating, born in 1993, all CSSs were created after the year 2000. This coincides with the launch of international initiatives, e.g., UN Global Compact and MDGs. The first two were market indexes: the DJSI World in 1999 and the FTSE4Good Developed Index in 2001. As shown previously, it is no coincidence that one of the drivers of corporate rating in ESG terms is the 
ISR. On the contrary, the arrival of another international initiative, the SDGs, has not promoted the development of new CSSs.

The European market has been the major driver of CSSs, by contrast, only 4 CSSs have been developed in North America: the DJSI World, the Global CR RepTrak 100, the MSCI World ESG Leaders Index and the World's Most Sustainable Corporations-Global 100.

At the scientific level, five CSSs have not been located in any of the analyzed articles: the GCX, the GSLI, the Supplier CSR Rating, The Sustainability Yearbook and the World's Most Sustainable Corporations-Global 100. Thus, most of the CSSs used in the articles are Indexes. In a business sphere, to a greater or lesser extent, all CSSs appear in all the analyzed corporate reports and websites (see Table 1). The last report, the Sustainalytics' ESG Risk Rating, was released in 2018; therefore, this CSS has not yet been used in scientific articles and by companies.

All CSSs are global and multi-sectorial, and measure corporate sustainability, corporate ESG criteria or CSR. It is to be noted that the FTSE4Good Developed Index and the ISS-oekom Corporate Rating mention in their evaluation processes that they measure the companies' contribution to the achievement of the SDGs. Although new CSSs are not being developed after the launch of the SDGs, the already existing CSSs are implementing the SDGs in their evaluation processes.

The "Block 2: Economic, financial and stock market criteria used to elaborate the CSSs" (see Table A2) identifies and analyzes the following CSS variables (see Table 3):

Table 3. Variables by CSS included in the Block 2.

\begin{tabular}{ll}
\hline Variable & Explanation \\
\hline $\begin{array}{l}\text { (9) Reference Stock Index and/or Initial } \\
\text { Eligible Universe. }\end{array}$ & $\begin{array}{l}\text { Stock market index used by the CSSs to select the companies } \\
\text { evaluated. } \\
\text { Typology of the companies evaluated, e.g., listed companies, }\end{array}$ \\
$\begin{array}{ll}\text { (10) Type of eligible companies. } & \text { SMEs or multinational, companies from developed markets or } \\
\text { emerging markets, etc. }\end{array}$ \\
$\begin{array}{ll}\text { (11) Market or financial criteria used in the } \\
\text { selection of companies. }\end{array}$ & $\begin{array}{l}\text { Economic, financial or stock market issues used for the } \\
\text { (12) Market or financial criteria used in the }\end{array}$ \\
methodology. & $\begin{array}{l}\text { Economic, financial or stock market issues used for the } \\
\text { evaluation of companies. }\end{array}$ \\
\hline
\end{tabular}

The results of the Global CR RepTrak 100 are based on general public surveys. Due to this peculiar methodology, this CSS does not provide information corresponding to this criteria Block.

Given the fact that Indexes are managed by stock exchange operators, the majority of their selection universes are stock exchange indexes, e.g., the S\&P Global BMI in DJSI World or the FTSE Developed Index in FTSE4Good Developed Index. Thus, from the first stage of the evaluation process, Indexes are focused on shareholders and investors. The Rankings and Ratings do not specify this data, except the World's Most Sustainable Corporations-Global 100, which uses the MSCI ACWI stock market index.

A common factor for the CSSs is that they analyze the most important companies in the world. Consequently, these companies participate in the stock markets from Asia-Pacific, Europe, North America or Oceania. The Supplier CSR Rating does not considered the size of the analyzed companies, because its objective is to connect sustainable buyers and sustainable suppliers, regardless of size or market.

All CSSs use economic and/or stock market criteria in the selection of companies and/or in the evaluation process, except the Supplier CSR Rating and the Sustainalytics' ESG Risk Rating, which do not provide information on these aspects. Although the major objective of the CSSs is to evaluate the corporate sustainability, this data is particularly significant because the economic aspect has a great weight in the final rating.

The "Block 3: Methodological criteria used by the managers to elaborate the CSSs" (see Table A3) identifies and analyzes the following CSS variables (see Table 4): 
Table 4. Variables by CSS included in the Block 3.

\begin{tabular}{ll}
\hline Variable & Explanation \\
\hline (13) Selection and Exclusion Criterion. & $\begin{array}{l}\text { Non-economic issues used for the selection or exclusion } \\
\text { of companies evaluated. }\end{array}$ \\
(14) Number of criteria used. & $\begin{array}{l}\text { Structure of sustainability issues, with typology and } \\
\text { number, used for the evaluation of companies. } \\
\text { Differentiates those CSSs which have their own } \\
\text { evaluation process, and methodologies that have a } \\
\text { specific name are identified. }\end{array}$ \\
(15) Use of our own methodology. & $\begin{array}{l}\text { Differentiates those CSSs whose evaluation process are } \\
\text { verified by an independent third party, and the verifiers } \\
\text { are identified. }\end{array}$ \\
& $\begin{array}{l}\text { Format used by CSSs to show the results of their } \\
\text { evaluation processes, three typologies are differentiated: } \\
\text { (16) The evaluation process has external verification score and/or qualifications. }\end{array}$ \\
&
\end{tabular}

The measure used by the Indexes to show the results is the so-called weight, which is confirmed by the final ESG score with economic, financial or stock market factors. Each Index uses its own system, e.g., the float-adjusted market capitalization in the DJSI World and the ESI Excellence Global, the price-weighted with a weighting factor in the STOXX Global ESG Leaders Index, dividing each corporate score by the total sum of the scores of all companies in the Euronext Vigeo Eiris World 120, or weighted average by activity sector in the MSCI World ESG Leaders Index. Again, the exception is the Sustainalytics' ESG Risk Rating, which does not use any weighting criteria in its rating results.

On the other hand, all Rankings and Ratings and three Indexes (the ECPI World ESG Equity Index, the STOXX Global ESG Leaders Index and the Sustainalytics' ESG Risk Rating) show their corporate ratings through a score, in some cases the rank goes from 0 to 100 and in others, the rank goes from 0 to 120 .

Finally, seven CSSs uses performance bands, each with a specific number of bands: the ECPI World ESG Equity Index with 9 performance bands; the Global CR RepTrak 100 with 5 performance bands; the ISS-oekom Corporate Rating with 12 performance bands; the MSCI World ESG Leaders Index with 7 performance bands; the Sustainalytics' ESG Risk Rating with 5 performance bands; The Sustainability Yearbook with 4 performance bands; and the Supplier CSR Rating has two scales with 3 and 5 performance bands. These performance bands help to group companies with similar ratings, regardless of activity sector, and allow a more simple comparison.

The other variables of the Block do not differ between Indexes, Rankings and Ratings. The CSSs have similar selection and exclusion criteria, use their own methodologies (except the DJSI World which uses the methodology of The Sustainability Yearbook) and verify their evaluation processes externally (the Global CR RepTrak 100, the GSLI and the Sustainalytics' ESG Risk Rating do not provide this information). Each CSS uses a different structure of performance indicators but in general, the structures are similar.

The "Block 4: Criteria for describing the companies sample that constitute the Initial Universe and the Final Universe of the CSSs" (see Table A4) identifies and analyzes the following CSS variables (see Table 5): 
Table 5. Variables by CSS included in the Block 4.

\begin{tabular}{ll}
\hline Variable & Explanation \\
\hline (18) Number of companies in the final list. & $\begin{array}{l}\text { Differentiates those CSSs whose final list of evaluated companies } \\
\text { has a variable number of components in each edition, and those } \\
\text { CSSs whose final list of evaluated companies has a stationary } \\
\text { number of components in each edition. }\end{array}$ \\
& $\begin{array}{l}\text { Sectoral classification system used by each CSS, and three } \\
\text { typologies are differentiated: use an international system, create } \\
\text { an own classification using as reference an international system, } \\
\text { (19) Sectorial classification system used. }\end{array}$ \\
& $\begin{array}{l}\text { Differentiates those CSSs in whose final list all companies are } \\
\text { evaluated regardless of their activity sector, and those CSSs in } \\
\text { whose final list the companies evaluated are separated by activity }\end{array}$ \\
& $\begin{array}{l}\text { sector. } \\
\text { The Initial Universe is described, identifying the number of } \\
\text { companies composing it and the number of countries and activity } \\
\text { (21) Initial Universe. } \\
\text { sector represented. } \\
\text { The Final Universe is described, identifying the number of } \\
\text { companies composing it and the number of countries and activity } \\
\text { sector represented. }\end{array}$ \\
\hline
\end{tabular}

In this Block, the characteristics do not vary substantially among CSSs.

All CSSs are multi-sectorial, but they use three different methodologies to classify the activity sectors.

The first option is to use directly sectoral classification systems recognized internationally, e.g., Global Industry Classification Standard (GICS) or Industry Classification Benchmark (ICB). Four CSSs use this option (all are Indexes): the ECPI World ESG Equity Index, the ESI Excellence Global, the FTSE4Good Developed Index and the MSCI World ESG Leaders Index.

The second option is to develop a new classification using as reference the two international systems previously mentioned, GICS and ICB. Three CSSs use this option: the DJSI World and The Sustainability Yearbook with the SAM Industry Classification System and the World's Most Sustainable Corporations-Global 100 with the Corporate Knights Industry Group. The Sustainalytics' ESG Risk Rating uses this option, but it does not specify which is the applied international system.

The third option is to develop a system based on their own criteria. This option is selected by four CSSs: the Euronext Vigeo Eiris World 120, the GCX, the Global CR RepTrak 100 and the STOXX Global ESG Leaders Index.

The GSLI and the ISS-oekom Corporate Rating do not specify whether the classification system used in their evaluation processes is based on an international standard or on their own criteria. The Supplier CSR Rating does not provide this information.

Most CSSs have a variable number of companies in the final sample, eleven in total. In the other four, the number of companies in the final sample does not vary: the Euronext Vigeo Eiris World 120 with 120 companies, the GCX with 50 companies, and the Global CR RepTrak 100 and the World's Most Sustainable Corporations-Global 100 with 100 companies.

The "Block 5: Criteria that allow stakeholders to know the public information provided by the CSSs' managers" (see Table A5) identifies and analyzes the following CSS variables (see Table 6): 
Table 6. Variables by CSS included in the Block 5.

\begin{tabular}{ll}
\hline Variable & Explanation \\
\hline (23) How information is obtained for the evaluation process. & $\begin{array}{l}\text { The nature of the information used in the evaluation } \\
\text { processes is described, and the provider of this information } \\
\text { is identified. } \\
\text { Differentiates those CSSs which provide their methodology } \\
\text { publicly on their websites. } \\
\text { Differentiates those CSSs which provide the results of their } \\
\text { evaluation processes publicly on their websites. } \\
\text { The format used by the CSSs' managers to show the results } \\
\text { of their evaluation processes is described: index factsheet, } \\
\text { annual report, reports sent to the companies evaluated, } \\
\text { platforms on the manager's website, or other typology of } \\
\text { documents. } \\
\text { (25) Qualifications are public. }\end{array}$ \\
$\begin{array}{ll}\text { The renewal periods associated with each CSS are } \\
\text { identified, e.g., the update of evaluation process, the update } \\
\text { the index composition or the calculation of the index. } \\
\text { Differentiates those CSSs which provide an award label } \\
\text { and the name is identified. }\end{array}$ \\
(27) Renewal periods.
\end{tabular}

Eleven CSSs obtain the necessary information to develop their evaluation processes from public sources, except the ESI Excellence Global (information only provided by Vigeo Eiris), the Euronext Vigeo Eiris World 120 (does not provide this information), the GCX (information only provided by ISS-oekom) and the GSLI (does not provide this information).

The DJSI World, the ESI Excellence Global, the GCX, the STOXX Global ESG Leaders Index and The Sustainability Yearbook receive information from rating agencies, RobecoSAM, Vigeo Eiris, ISS-oekom, Sustainalytics, and RepRisk ESG Business Intelligence and Sustainalytics, respectively.

Seven CSSs have direct contact with the companies evaluated, with different contact levels. The ISS-oekom Corporate Rating, the MSCI World ESG Leaders Index, the Supplier CSR Rating, the Sustainalytics' ESG Risk Rating and The Sustainability Yearbook allow feedback to companies, and these can provide documentation that corroborates the public information collected for CSSs. The FTSE4Good Developed Index and the World's Most Sustainable Corporations-Global 100 maintain contact with companies only to verify the information collected, but companies cannot provide additional information. The Supplier CSR Rating and The Sustainability Yearbook submit specific questionnaires to companies, and this CSSs obtain additional information for the evaluation processes.

Therefore, all Ratings and Rankings, except the Global CR RepTrak 100, maintain a direct relationship with the companies, unlike Indexes, with only three components carrying out this practice: the FTSE4Good Developed Index, the MSCI World ESG Leaders Index and the Sustainalytics' ESG Risk Rating.

All CSSs, except the FTSE4Good Developed Index and the GSLI, have their methodology publicly available.

Regarding qualifications, the reading is different. The managers of the three Rankings publicly provide the constituents and the scores of the final classifications: The Global CR RepTrak 100 and The Sustainability Yearbook publish it in an annual report, but the World's Most Sustainable Corporations-Global 100 publish it annually on the manager website. Ratings submit their results to companies directly and individually, and the access to all qualifications is only private, via an online platform. On the other hand, Indexes have three typologies to show their qualifications. Three Indexes only announce their constituents: the DJSI World in a specific document, the Euronext Vigeo Eiris World 120 in the index factsheet, and the GCX in the annual report. Three other indexes announce constituents and weights: the ECPI World ESG Equity Index in a specific document, the ESI Excellence Global in the index factsheet, and the STOXX Global ESG Leaders Index in a specific document. The remaining four indexes do not provide neither of these two data: the FTSE4Good Developed Index, the GSLI, the MSCI World ESG Leaders Index and the Sustainalytics' ESG Risk Rating. 
The Rankings update annually the components of their final list. Although the Ratings do not elaborate a final performance list, the information of the companies is updated annually. Indexes have several specific cases. The DJSI World, the GSLI, the MSCI World ESG Leaders Index, the STOXX Global ESG Leaders Index and the Sustainalytics' ESG Risk Rating update annually their constituents. The ESI Excellence Global, the Euronext Vigeo Eiris World 120, the FTSE4Good Developed Index and the GCX are revised semi-annually. The index constituents of the ECPI World ESG Equity Index are reviewed four times a year.

On the other hand, due to its stock market nature, six Indexes are calculated in real time or daily: the DJSI World, the ECPI World ESG Equity Index, the ESI Excellence Global, the Euronext Vigeo Eiris World 120, the FTSE4Good Developed Index and the STOXX Global ESG Leaders Index. In the case of the GCX, the GSLI, the MSCI World ESG Leaders Index and the Sustainalytics' ESG Risk Rating, they do not provide this information.

Finally, five CSSs provide a prize label that can be used by companies to show their stakeholders their good performance: the DJSI World with the DJSI Member logo; the ESI Excellence Global with the Ethibel PIONEER Investment Register, the Ethibel EXCELLENCE Investment Register and the Included in Ethibel Sustainability Index EXCELLENCE Global; the ISS-oekom Corporate Rating with the Prime Status; the Supplier CSR Rating with Gold, Silver and Bronze logo; and The Sustainability Yearbook with the Gold, Silver and Bronze Class.

By performing a comparative analysis based on the five criteria, it has been possible to identify the CSSs' common characteristics and form affinity patterns to allow the classification of the CSSs to be divided into 3 major groups: Indexes, Rankings and Ratings (see Table 7). These groups coincide with previous research $[8,9]$. The first group (Indexes) includes the DJSI World, the ECPI World ESG Equity Index, the ESI Excellence Global, the Euronext Vigeo Eiris World 120, the FTSE4Good Developed Index, the CGX, the GSLI, the MSCI World ESG Leaders Index, the STOXX Global ESG Leaders Index and the Sustainalytics' ESG Risk Rating. The second group (Rankings) is composed by the Global CR RepTrak 100, The Sustainability Yearbook and the World's Most Sustainable Corporations-Global 100. Finally, the Ratings are the ISS-oekom Corporate Rating and the Supplier CSR Rating.

After a CSSs' comparative analysis according to the variables of the five Blocks, the 15 CSSs have been grouped into Indexes, Rankings and Ratings (see Table 7).

Table 7. Classification of CSSs according to their main characteristics and target stakeholders.

\begin{tabular}{|c|c|c|}
\hline CSS Name & Typology & Major Target Stakeholders \\
\hline DJSI World. & Index. & Shareholders, investors and executives. \\
\hline ECPI World ESG Equity Index. & Index. & Shareholders, investors and executives. \\
\hline ESI Excellence Global. & Index. & $\begin{array}{l}\text { Multi-stakeholder, but shareholders, investors } \\
\text { and executive principally. }\end{array}$ \\
\hline Euronext Vigeo Eiris World 120. & Index. & $\begin{array}{l}\text { Multi-stakeholder, but shareholders, investors } \\
\text { and executive principally. }\end{array}$ \\
\hline FTSE4Good Developed Index. & Index. & Shareholders, investors and executives. \\
\hline GCX. & Index. & Shareholders, investors and executives. \\
\hline GSLI. & Index. & Shareholders, investors and executives. \\
\hline MSCI World ESG Leaders Index. & Index. & Shareholders, investors and executives. \\
\hline STOXX Global ESG Leaders Index. & Index. & Shareholders, investors and executives. \\
\hline Sustainalytics' ESG Risk Rating. & Index. & $\begin{array}{l}\text { Multi-stakeholder, but important for the } \\
\text { evaluated company. }\end{array}$ \\
\hline Global CR RepTrak 100. & Ranking. & Multi-stakeholder. \\
\hline The Sustainability Yearbook. & Ranking. & Multi-stakeholder. \\
\hline $\begin{array}{l}\text { World's Most Sustainable } \\
\text { Corporations-Global } 100 .\end{array}$ & Ranking. & Multi-stakeholder. \\
\hline ISS-oekom Corporate Rating. & Rating. & Multi-stakeholder. \\
\hline Supplier CSR Rating. & Rating. & $\begin{array}{l}\text { Suppliers and purchasing companies, but } \\
\text { important information for the evaluated company }\end{array}$ \\
\hline
\end{tabular}


CSSs measure the implementation level of CSR tools in the companies, and CSR takes into account the stakeholders' interest. With this premise, it can be determined that CSSs are designed to be used by all stakeholders. The comparative analysis has allowed to establish that in practice, each group of CSS is focused on specific stakeholders (see Table 7). Most indexes aim clearly at shareholders, investors and executives. By contrast, Ratings and Rankings have a multi-stakeholder approach and they are more open instruments, which, in theory, can be used by any stakeholder.

The financial market has been pioneer to boost the measurement of corporate performance in ESG terms, and has tried to do it with credibility. However, the differences between the CSSs analyzed in this study show that, there still is a long way to eliminate the subjective halo surrounding the CSSs' universe. A consequence of this is that the qualification obtained by a company in different CSSs can hardly be comparable [57]. In addition, the scores can be very different. Two criteria used to define the comparability level of the final sample of companies are the geographical scope covered by the CSS and the activity sector of the evaluated companies.

Generally, the CSSs qualify the most important companies of developed markets, more specifically, from Asia-Pacific, Europe, North America and Oceania. This can cause two readings. On the one hand, the performance of companies belonging to emerging or undeveloped markets, despite their great contribution to sustainable development in countries closely linked to several of the difficulties faced by sustainability, remains excluded from this measuring. On the other hand, priority is given to the activities and operations held by the evaluated companies in developed countries, excluding those less correct practices-which could deteriorate their results-that these companies may be carrying out in developing countries.

Most CSSs are multi-sectorial. Many analyzed methodologies consider the sectorial differences through various solutions. Some send Industry-specific questionnaires to companies, e.g., The Sustainability Yearbook. Other CSSs use performance indicators weighted for each sector, e.g., the World's Most Sustainable Corporations-Global 100. The most widely used option is to select a specific number of indicators for each activity sector: the DJSI World, the FTSE4Good Developed Index, the GCX, the GSLI, the ISS-oekom Corporate Rating, the MSCI World ESG Leaders Index, the STOXX Global ESG Leaders Index, the Sustainalytics' ESG Risk Rating, The Sustainability Yearbook and the World's Most Sustainable Corporations-Global 100. By contrast, the ECPI World ESG Equity Index, the ESI Excellence Global, the Euronext Vigeo Eiris World 120, the Global CR RepTrak 100 and the Supplier CSR Rating evaluate all companies equally, regardless of their activity sectors. Therefore, since industries do not tackle the same risk, opportunities and problems comparability in sectoral terms is difficult to calibrate.

Simultaneously, in recent years companies are disclosing their ratings to different stakeholders. Even so, this is not a general practice in all sectors, and in many cases, this information is published in sections specifically for investors or shareholders. For example, the telecommunications company Deutsche Telekom announces its results in the website section "Investors Relations" and in the "Sustainable Finance" chapter of its sustainability report. The utility Enel goes a step further and publishes all its sustainability information in the website section "Investors".

Observing this panorama, the stakeholders, as well as those who are not shareholders, investors or company directors, may ignore the existence of CSSs and if faced with them, they may have difficulty in interpreting their results.

\section{Discussion and Conclusions}

This article investigates the current situation of CSSs through the revision of their methodologies and comparative analysis of a specific number of characteristics that describe the CSSs. Afterwards, it divides them into three large groups according to their typology: Indexes, Ratings and Rankings. The selected CSSs are multi-sectorial and global, and they have relevance in the academic community and widely used by the major international companies. Scientific articles, public information provided by the CSSs' managers in the first half of 2019 and the sustainability report, the annual reports and 
websites of the major companies of the sectors of telecommunications, utilities and wind turbine manufacturers have been used. This study consists of a qualitative characterization and a comparative analysis of the CSSs, based on the most representative criteria to describe their nature. The grouping of the CSSs has been carried out by determining and associating their common characteristics that allow cataloguing each one of the three groups that classify the CSSs, Indexes, Rankings and Ratings.

The research is focused on the tools that qualify the companies in ESG terms. This allows extending the spectrum of the study sample to non-financial CSSs and avoiding the exclusive use of CSSs developed exclusively for stock market purposes. The development of products that from the beginning have been oriented only to investors and shareholders is a problem for the industry of rating agencies. This causes the CSSs to have a biased concept of sustainability and therefore, their contribution to sustainable development is diminished. Similarly, the comparative analysis follows a multi-stakeholder approach and not only economic-financial criteria focused on investors or shareholders.

Since the launch of the UN Global Compact and MDGs, the tools that measure sustainability corporate performance have proliferated. This has created a broad and heterogeneous universe of CSSs. In addition, in most cases, CSSs have not been developed according to "Stakeholder Theory". This document aims to put order in the CSSs' universe through a comparative analysis of the most relevant CSSs in scientific literature and in the business world, according to 28 variables grouped into five thematic Blocks, identified as the most suitable for their description. This article presents clear, concise and useful information on the methodologies and most relevant characteristics of the CSSs, and based on the "Stakeholder Theory". An important contribution is made to the existing literature by identifying the CSSs that adjust to the "Stakeholder Theory" and, therefore, by identifying which are the most suitable CSSs to be used by all stakeholders. Likewise, thanks to the use of more general comparative criteria-not only criteria of economic-financial nature-arguments have been added so that all stakeholders can have a critical view when interpreting the characteristics that define CSSs. Thus, the stakeholders can select the ideal CSS for their interests, expectations or needs, and use the corporate qualifications that CSSs provide to achieve their objectives. For example, investors can adapt optimally their investment portfolio to a sustainable approach, consumers can approach their purchasing strategies on the companies with the best ESG performance, and employees can select the most attractive companies to carry out their professional work. Additionally, companies can select suppliers who will improve their indirect sustainability impacts, or to know the ESG performance of their competitors and have a reference point for improving and increasing their own performance. Finally, academics can select the ideal CSS for their research framework.

The "Stakeholder Theory" is a fundamental pillar of CSR that has fostered the paradigm shift in the company-society relationship. CSR has two main lines: the integration of stakeholders' interests in the definition of corporate strategies, and the correct management of ESG criteria to implement the TBL philosophy in the core of companies and be accountable to stakeholders. For the success of any strategy, policy or tool related to corporate sustainability, they must be based on the satisfaction of the interests, needs and expectations of all stakeholders. CSSs are widely used indicators to measure and quantify the ESG performance of companies. Therefore, they should be developed as tools to be used by any stakeholder, regardless of their typology. As shown in this study, most of the CSSs analyzed Indexes are made or managed by stock exchange operators or ESG rating agencies whose products are used by individual and institutional investors. From their origin, CSSs are exclusively tools aimed at the financial and capital markets. In addition, weighing economic or financial criteria affects decisively the CSSs' final ratings in all aspects: qualitatively, quantitatively or in the weight form. Although Rating and Rankings have a broader multi-stakeholder approach, they also have a high level of economic-financial bias.

Regarding, the limitations of the research, the most relevant limitation is the limited information provided by rating agencies and stock exchange operators about the methodologies and criteria used in their CSSs development. Even when this information has been found in a simple way, its high 
level of economic-financial bias has hindered all analysis with a multi-stakeholder perspective. As compared to the Indexes, the number of constituents of the Rankings and Ratings sample is limited. Other researchers may extend the sample of Ratings and Rankings.

This study has focused on the CSSs that qualify the corporate performance around the three ESG pillars. Future research lines may expand the spectrum of comparative analysis to mono-vectorial CSSs that measure and qualify corporate performance in the single factor that contributes to sustainable development, such as climate change, water management or worker's diversity and inclusion.

Author Contributions: B.D.-C. has carried out all the stages of the paper, conceptualization, conception, design, research, analysis and conclusions, writing, and final review. J.R.O.-O. and R.M. were involved in the supervision and final review of the paper. All authors participated in the conceptualization, conception and design of the paper. All authors have read and agreed to the published version of the manuscript.

Funding: This research was funded by IHOBE, Basque Government.

Acknowledgments: This research was founded by IHOBE, Environmental Management Public Agency of the Basque Government, and was carried out in collaboration with the Department of Graphic Design and Engineering Projects of the University of the Basque Country (UPV/EHU).

Conflicts of Interest: The authors declare no conflict of interest. 


\section{Appendix A}

Table A1. Block 1: General information about the CSSs.

\begin{tabular}{|c|c|c|c|c|c|c|c|c|c|c|c|c|}
\hline \multirow[b]{2}{*}{ CSS } & \multirow[b]{2}{*}{ Launch Year } & \multicolumn{3}{|c|}{ CSSs' Managers } & \multirow{2}{*}{$\begin{array}{c}\text { Generally } \\
\text { Accepted in } \\
\text { Science }\end{array}$} & \multicolumn{3}{|c|}{ Mentioned by Companies } & \multirow{2}{*}{$\begin{array}{l}\text { Appears } \\
\text { under Rate } \\
\text { the Raters }\end{array}$} & \multirow{2}{*}{$\begin{array}{l}\text { Evaluation } \\
\text { Theme }\end{array}$} & \multirow{2}{*}{$\begin{array}{l}\text { Geographical } \\
\text { Scope }\end{array}$} & \multirow{2}{*}{$\begin{array}{l}\text { Sector } \\
\text { Approach }\end{array}$} \\
\hline & & Name & Typology & Country & & Telecommunications & Utilities & $\begin{array}{l}\text { Wind Turbine } \\
\text { Manufacturers }\end{array}$ & & & & \\
\hline DJSI World. & 1999. & $\begin{array}{l}\text { S\&P Dow } \\
\text { Jones Indices. } \\
\text { RobecoSAM. }\end{array}$ & $\begin{array}{l}\text { Indexes provider. } \\
\text { Privately } \\
\text { investment } \\
\text { manager. }\end{array}$ & $\begin{array}{l}\text { USA. } \\
\text { Switzerland. }\end{array}$ & $\checkmark$ & $\checkmark$ & $\checkmark$ & $\checkmark$ & & ESG. & International. & Multi-sector. \\
\hline $\begin{array}{l}\text { ECPI World ESG } \\
\text { Equity Index. }\end{array}$ & 2007. & ECPI Group. & $\begin{array}{l}\text { Advisory } \\
\text { services. }\end{array}$ & Italy. & $\checkmark$ & $\checkmark$ & $\checkmark$ & $\checkmark$ & & $\begin{array}{l}\text { ESG, socially } \\
\text { responsible } \\
\text { and } \\
\text { sustainability. }\end{array}$ & International. & Multi-sector. \\
\hline $\begin{array}{l}\text { ESI Excellence } \\
\text { Global. }\end{array}$ & $2013^{1}$. & $\begin{array}{l}\text { Vigeo Eiris. } \\
\text { Forum } \\
\text { Ethibel. } \\
\text { Euronext. }\end{array}$ & $\begin{array}{l}\text { Rating and } \\
\text { advisory service. } \\
\text { Rating, audits } \\
\text { and certification. } \\
\text { Stock exchange } \\
\text { operator. }\end{array}$ & $\begin{array}{l}\text { France. } \\
\text { Belgium. } \\
\text { France. }\end{array}$ & $\checkmark$ & $\checkmark$ & $\checkmark$ & $\checkmark$ & $\checkmark$ & Sustainability. & International. & Multi-sector. \\
\hline $\begin{array}{l}\text { Euronext Vigeo } \\
\text { Eiris World } 120 .\end{array}$ & $2013^{2}$. & $\begin{array}{l}\text { Vigeo Eiris. } \\
\text { Euronext. }\end{array}$ & $\begin{array}{l}\text { Rating and } \\
\text { advisory service. } \\
\text { Stock exchange } \\
\text { operator. }\end{array}$ & $\begin{array}{l}\text { France. } \\
\text { France. }\end{array}$ & $\checkmark$ & $\checkmark$ & $\checkmark$ & & $\checkmark$ & $\begin{array}{l}\text { Sustainability } \\
\text { and } \\
\text { Corporate } \\
\text { Responsibility. }\end{array}$ & International. & Multi-sector. \\
\hline $\begin{array}{l}\text { FTSE4Good } \\
\text { Developed Index. }\end{array}$ & 2001. & $\begin{array}{l}\text { FTSE } \\
\text { Russell. } \\
\text { Börse }\end{array}$ & $\begin{array}{l}\text { Stock market } \\
\text { indexes provider. } \\
\text { Stock Exchange. }\end{array}$ & UK. & $\checkmark$ & $\checkmark$ & $\checkmark$ & $\checkmark$ & $\checkmark$ & $\begin{array}{l}\text { ESG, aligned } \\
\text { with SDGs. }\end{array}$ & International. & Multi-sector. \\
\hline GCX. & 2007. & $\begin{array}{l}\text { Hannover. } \\
\text { ISS-oekom. }\end{array}$ & $\begin{array}{l}\text { Research and } \\
\text { rating agency. }\end{array}$ & $\begin{array}{l}\text { Germany. } \\
\text { Germany. }\end{array}$ & & & & $\checkmark$ & & Sustainability. & International. & Multi-sector. \\
\hline $\begin{array}{l}\text { Global CR RepTrak } \\
100 .\end{array}$ & 2012. & $\begin{array}{l}\text { Reputation } \\
\text { Institute (RI). }\end{array}$ & $\begin{array}{l}\text { Research and } \\
\text { analysis agency. } \\
\text { Research and }\end{array}$ & USA. & $\checkmark$ & & & & & Sustainability. & International. & Multi-sector. \\
\hline GSLI. & $2012^{3}$. & $\begin{array}{l}\text { Sustainalytics. } \\
\text { Solactive. } \\
\text { UBS. }\end{array}$ & $\begin{array}{l}\text { analysis agency. } \\
\text { Financial indices } \\
\text { provider. } \\
\text { Financial services } \\
\text { company. }\end{array}$ & $\begin{array}{l}\text { Netherlands. } \\
\text { Germany. } \\
\text { Switzerland. }\end{array}$ & & $\checkmark$ & $\checkmark$ & & & ESG. & International. & Multi-sector. \\
\hline $\begin{array}{l}\text { ISS-oekom } \\
\text { Corporate Rating. }\end{array}$ & 1993. & ISS-oekom. & $\begin{array}{l}\text { Research and } \\
\text { rating agency. }\end{array}$ & Germany. & $\checkmark$ & $\checkmark$ & $\checkmark$ & $\checkmark$ & $\checkmark$ & $\begin{array}{l}\text { ESG, aligned } \\
\text { with SDGs. }\end{array}$ & International. & Multi-sector \\
\hline $\begin{array}{l}\text { MSCI World ESG } \\
\text { Leaders Index. }\end{array}$ & 2007. & MSCI. & $\begin{array}{l}\text { Stock market } \\
\text { indexes provider. }\end{array}$ & USA. & $\checkmark$ & $\checkmark$ & $\checkmark$ & $\checkmark$ & $\checkmark$ & Sustainability. & International. & Multi-sector. \\
\hline $\begin{array}{l}\text { STOXX Global ESG } \\
\text { Leaders Index. }\end{array}$ & 2011. & STOXX. & Indexes provider. & Switzerland. & $\checkmark$ & $\checkmark$ & $\checkmark$ & $\checkmark$ & & ESG. & International. & Multi-sector. \\
\hline $\begin{array}{l}\text { Supplier CSR } \\
\text { Rating. }\end{array}$ & 2007. & EcoVadis. & Rating agency. & France. & & $\checkmark$ & $\checkmark$ & $\checkmark$ & $\checkmark$ & Sustainability. & International. & Multi-sector \\
\hline
\end{tabular}


Table A1. Cont.

\begin{tabular}{|c|c|c|c|c|c|c|c|c|c|c|c|c|}
\hline \multirow[b]{2}{*}{ CSS } & \multirow[b]{2}{*}{ Launch Year } & \multicolumn{3}{|c|}{ CSSs' Managers } & \multirow{2}{*}{$\begin{array}{c}\text { Generally } \\
\text { Accepted in } \\
\text { Science }\end{array}$} & \multicolumn{3}{|c|}{ Mentioned by Companies } & \multirow{2}{*}{$\begin{array}{l}\text { Appears } \\
\text { under Rate } \\
\text { the Raters }\end{array}$} & \multirow{2}{*}{$\begin{array}{l}\text { Evaluation } \\
\text { Theme }\end{array}$} & \multirow{2}{*}{$\begin{array}{l}\text { Geographical } \\
\text { Scope }\end{array}$} & \multirow{2}{*}{$\begin{array}{l}\text { Sector } \\
\text { Approach }\end{array}$} \\
\hline & & Name & Typology & Country & & Telecommunications & Utilities & $\begin{array}{l}\text { Wind Turbine } \\
\text { Manufacturers }\end{array}$ & & & & \\
\hline $\begin{array}{l}\text { Sustainalytics' ESG } \\
\text { Risk Rating. }\end{array}$ & 2018. & Sustainalytics. & $\begin{array}{l}\text { Research and } \\
\text { analysis agency. }\end{array}$ & Netherlands. & & & & & $\checkmark$ & ESG. & International. & Multi-sector. \\
\hline $\begin{array}{l}\text { The Sustainability } \\
\text { Yearbook. }\end{array}$ & $2004^{4}$. & RobecoSAM. & $\begin{array}{l}\text { Privately } \\
\text { investment } \\
\text { manager. }\end{array}$ & Switzerland. & & $\checkmark$ & $\checkmark$ & & $\checkmark$ & ESG. & International. & Multi-sector. \\
\hline $\begin{array}{l}\text { World's Most } \\
\text { Sustainable } \\
\text { Corporations_Global } \\
100 .\end{array}$ & 2005. & $\begin{array}{l}\text { Corporate } \\
\text { Knights (CK). } \\
\text { Thomson } \\
\text { Reuter. }\end{array}$ & $\begin{array}{l}\text { Media and } \\
\text { information firm. } \\
\text { Media and } \\
\text { information firm. }\end{array}$ & $\begin{array}{l}\text { Canada. } \\
\text { USA. }\end{array}$ & & & $\checkmark$ & $\checkmark$ & & Sustainability. & International. & Multi-sector. \\
\hline
\end{tabular}

Notes: ${ }^{1}$ The Ethibel Sustainability Index Excellence Global NR has been published since this year; Ethibel Sustainability Index Excellence Global and Ethibel Sustainability Index Excellence

Global GR are published since 2002. ${ }^{2}$ On the Vigeo Eiris website, the factsheet of the index since 2012 is published. ${ }^{3}$ Not specified. However, in the latest edition of the index factsheet,

there is information since 2012 (Gross Total Returns). ${ }^{4}$ RobecoSAM performs its analysis and ratings since 1999 (CSA methodology). 
Table A2. Block 2: Economic, financial and stock market criteria used to elaborate CSSs

\begin{tabular}{|c|c|c|c|c|}
\hline CSS & $\begin{array}{l}\text { Reference Stock Index and/or Initial } \\
\text { Eligible Universe }\end{array}$ & Type of Eligible Companies & $\begin{array}{l}\text { Market or Financial Criteria used in the } \\
\text { Selection of Companies }\end{array}$ & $\begin{array}{l}\text { Market or Financial Criteria used in } \\
\text { the Methodology }\end{array}$ \\
\hline DJSI World. & $\begin{array}{l}\text { S\&P Global BMI. } \\
\text { Equity Universe. }\end{array}$ & Listed companies. & $\begin{array}{l}\text { Existing Constituents threshold: above } \\
\text { US } \$ 500 \text { million. }\end{array}$ & $\begin{array}{l}\text { The index is float-adjusted market } \\
\text { capitalization weighted. } \\
\text { The price return, gross total return and net } \\
\text { total return are calculated. }\end{array}$ \\
\hline ECPI World ESG Equity Index. & ECPI Global Ethical Equity. & Listed companies of developed markets. & $\begin{array}{l}\text { Free float-adjusted market criteria to } \\
\text { initial selection of the companies: } \\
\text { companies must have a minimum } \\
\text { market capitalization of } € 400 \text { million. }\end{array}$ & $\begin{array}{l}\text { Financial criteria to final selection of the } \\
\text { companies which make up the index. } \\
\text { The investability screens used are: minimum } \\
\text { market capitalization, minimum free float } \\
\text { adjusted market capitalization, minimum } \\
\text { liquidity and minimum free float. } \\
\text { The price index, the gross (net) total return } \\
\text { index and the Hedged index are calculated. } \\
\text { Evaluation of controversial practices } \\
\text { considers the potential impact on company's } \\
\text { profitability. }\end{array}$ \\
\hline ESI Excellence Global. & $\begin{array}{l}\text { Russell Global Index. } \\
\text { Ethibel Excellence Register. }\end{array}$ & Companies listed on the stock exchange. & $\begin{array}{l}\text { Include companies whose free float } \\
\text { market capitalization is superior to } € 10 \\
\text { bn and remove companies with a free } \\
\text { float market capitalization inferior to } € 5 \\
\text { bn. }\end{array}$ & $\begin{array}{l}\text { The market capitalization is used for the } \\
\text { calculation of weights. } \\
\text { The price index, the gross total return index } \\
\text { and the net total return index are calculated. }\end{array}$ \\
\hline Euronext Vigeo Eiris World 120. & $\begin{array}{l}\text { World Equitics Universe. } \\
\text { All companies included in the related } \\
\text { Euronext Vigeo universe. }\end{array}$ & $\begin{array}{l}\text { The largest free-float market } \\
\text { capitalizations in North America, } \\
\text { Asia-Pacific and Europe. }\end{array}$ & Not specified. & $\begin{array}{l}\text { The market capitalization is used for the } \\
\text { calculation of weights. } \\
\text { The price index, the gross total return index } \\
\text { and the net total return index are calculated. }\end{array}$ \\
\hline FTSE4Good Developed Index. & $\begin{array}{l}\text { FTSE Developed Index, FTSE All-World } \\
\text { Index, FTSE All-Share Index and Russell } \\
1000 \text { Index. }\end{array}$ & $\begin{array}{l}\text { Companies that are in developed and } \\
\text { emerging markets. }\end{array}$ & Not specified. & $\begin{array}{l}\text { The index is calculated based on price and } \\
\text { total return methodologies. }\end{array}$ \\
\hline GCX. & ISS-oekom Universe. & $\begin{array}{l}\text { Large corporations (large caps) and } \\
\text { small and medium-sized companies. }\end{array}$ & $\begin{array}{l}\text { Minimum capitalization value of at least } \\
€ 100 \text { million. } \\
\text { A financial analysis is done it ensure that } \\
\text { the selected companies meet minimum } \\
\text { market capitalization requirements. }\end{array}$ & $\begin{array}{l}\text { The market capitalization is used for the } \\
\text { calculation of weight (minimum } \\
\text { requirements). }\end{array}$ \\
\hline Global CR RepTrak 100. & Not specified. & Not specified. & Not specified. & Not specified. \\
\hline GSLI. & $\begin{array}{l}\text { Sustainalytics' ESG Rating Universe. } \\
\text { Global Compact signatories. }\end{array}$ & Listed companies. & $\begin{array}{l}\text { The free-float market cap must be larger } \\
\text { than } \$ 500 \mathrm{mn} \text { and the average daily } \\
\text { trading over the past three months } \\
\text { above } \$ 10 \mathrm{mn} \text { for two consecutive years. }\end{array}$ & $\begin{array}{l}\text { In the methodology are used market flotation } \\
\text { and financial and liquidity criteria (e.g., } \\
\text { EBIT). }\end{array}$ \\
\hline ISS-oekom Corporate Rating. & $\begin{array}{l}\text { Two partial research universes: } \\
\text { "Developed Markets Universe (DMU)" } \\
\text { and "Emerging Markets Universe } \\
\text { (EMU). }\end{array}$ & $\begin{array}{l}\text { The major stock indices of developed } \\
\text { and emerging markets, national and } \\
\text { international. } \\
\text { Companies of small and mid-cap indices } \\
\text { in developed markets. }\end{array}$ & Not specified. & $\begin{array}{l}\text { Financial data are used (like the proportion of } \\
\text { net sales generated by products and services } \\
\text { that contribute to or hinder the achievement } \\
\text { of sustainability targets). } \\
\text { The Controversy Monitor assess reputational } \\
\text { and financial risks, associated with } \\
\text { companies' negative environmental and } \\
\text { social impacts. }\end{array}$ \\
\hline
\end{tabular}


Table A2. Cont.

\begin{tabular}{|c|c|c|c|c|}
\hline CSS & $\begin{array}{l}\text { Reference Stock Index and/or Initial } \\
\text { Eligible Universe }\end{array}$ & Type of Eligible Companies & $\begin{array}{l}\text { Market or Financial Criteria used in the } \\
\text { Selection of Companies }\end{array}$ & $\begin{array}{l}\text { Market or Financial Criteria used in } \\
\text { the Methodology }\end{array}$ \\
\hline MSCI World ESG Leaders Index. & $\begin{array}{l}\text { MSCI World Index. } \\
\text { MSCI Global Investable Market Indexes } \\
\text { (GIMI). }\end{array}$ & $\begin{array}{l}\text { Large and mid-cap companies in } \\
\text { developed markets. }\end{array}$ & Not specified. & $\begin{array}{l}\text { The index is weighted by free float-adjusted } \\
\text { market capitalization. }\end{array}$ \\
\hline STOXX Global ESG Leaders Index. & $\begin{array}{l}\text { STOXX Global } 1800 \text { Index: } 600 \text { Europe, } \\
600 \text { America and } 600 \text { Asia/Pacific. }\end{array}$ & Companies listed on the stock exchange. & $\begin{array}{l}\text { A minimum three-month average daily } \\
\text { trading volume (ADTV) of } 1 \text { million U.S. } \\
\text { dollars is required. }\end{array}$ & $\begin{array}{l}\text { The index is weighted by free-float market } \\
\text { cap combined with a cap factor that depends } \\
\text { on a company's aggregate ESG KPI score. } \\
\text { The index is available in price and gross } \\
\text { return versions. }\end{array}$ \\
\hline Supplier CSR Rating. & Not specified. & $\begin{array}{l}\text { SMEs and multinationals, buyers and } \\
\text { suppliers. }\end{array}$ & Not specified. & Not specified. \\
\hline Sustainalytics' ESG Risk Rating. & Not specified. & $\begin{array}{l}\text { Companies that are in the major global } \\
\text { and regional equity and fixed incomes } \\
\text { indices. }\end{array}$ & Not specified. & Not specified. \\
\hline The Sustainability Yearbook. & Not specified. & $\begin{array}{l}\text { Most important companies in terms of } \\
\text { market capitalization. }\end{array}$ & Not specified. & $\begin{array}{l}\text { A financial materiality analysis is performed } \\
\text { on each company. } \\
\text { The industry-specific questionnaire is } \\
\text { focusing on financially-relevant economic, } \\
\text { environmental and social criteria }\end{array}$ \\
\hline $\begin{array}{l}\text { World's Most Sustainable } \\
\text { Corporations-Global } 100 .\end{array}$ & MSCI ACWI. & Publicly listed companies. & 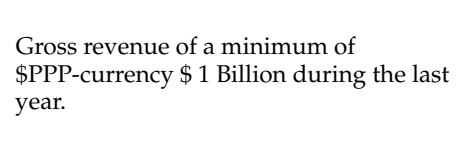 & $\begin{array}{l}\text { The F-Score is a measure of the financial } \\
\text { strength of a company. } \\
\text { The CK Financial Sanction Screen measures } \\
\text { the amount of money paid in fines for each } \\
\text { company. }\end{array}$ \\
\hline
\end{tabular}


Table A3. Block 3: Methodological criteria used by the managers to elaborate the CSSs.

\begin{tabular}{|c|c|c|c|c|c|}
\hline CSS & Selection \& Exclusion Criterion & Number of Criteria Used & Use of Their Own Methodology & The Evaluation Process has External Verification & Unit of Scoring or Qualification \\
\hline DJSI World. & $\begin{array}{l}\text { General and sectoral ESG } \\
\text { indicators. } \\
\text { Best-in-class. } \\
\text { Ethical exclusion of controversial } \\
\text { sectors. }\end{array}$ & $\begin{array}{l}38 \text { Criteria: Criteria of CSA } \\
\text { process of The Sustainability } \\
\text { Yearbook. }\end{array}$ & & $\begin{array}{l}\text { The DJSI Index Committee (S\&P Dow Jones Indices } \\
\text { and RobecoSAM representatives) oversees the } \\
\text { management of all changes affecting the index, and } \\
\text { the additions to and deletions from these indices. } \\
\text { The controversial sectors analyses are carried by } \\
\text { Sustainalytics and RobecoSAM. }\end{array}$ & $\begin{array}{l}\text { Weight: by float-adjusted market } \\
\text { capitalization. }\end{array}$ \\
\hline $\begin{array}{l}\text { ECPI World ESG } \\
\text { Equity Index. }\end{array}$ & $\begin{array}{l}\text { General ESG indicators and } \\
\text { socially responsible and } \\
\text { sustainability criteria. } \\
\text { Best-in-class. } \\
\text { General exclusion by } \\
\text { controversial sectors. }\end{array}$ & $\begin{array}{l}2 \text { ESG Section. } \\
8 \text { Categories. } \\
38 \text { Aspects. } \\
100+\text { KPIs. }\end{array}$ & ECPI ESG Rating Methodology. & $\begin{array}{l}\text { The quality of the ESG research and rating process } \\
\text { is certified according to international ISO quality } \\
\text { standards and verified on an annual basis by a third } \\
\text { party, independent international auditor. }\end{array}$ & $\begin{array}{l}\text { Weight. } \\
\text { Score: } 0 \text {-120. } \\
\text { Qualification: ECPI ESG Rating, } \\
\text { score is grouped into } 9 \\
\text { performance bands } \rightarrow \text { EEE/EEE- } \\
\text { (Very Good); EE+/EE/EE- (Good) } \\
\text { E+/E/E- (Fair); and F } \\
\text { (Poor-ineligible). }\end{array}$ \\
\hline ESI Excellence Global. & $\begin{array}{l}\text { General sustainability indicators. } \\
\text { Best-in-class. } \\
\text { General exclusion criteria and } \\
\text { controversial activities. } \\
\text { Performance in Corporate }\end{array}$ & 6 Key Areas. & $\checkmark$ & $\begin{array}{l}\text { ESI Committee is responsible for monitoring the } \\
\text { selection of constituents for the index and ensuring } \\
\text { that the index offers a reliable and representative } \\
\text { view of the market. }\end{array}$ & $\begin{array}{l}\text { Weight: by free float adjusted } \\
\text { market capitalization. }\end{array}$ \\
\hline $\begin{array}{l}\text { Euronext Vigeo Eiris } \\
\text { World } 120 \text {. }\end{array}$ & $\begin{array}{l}\text { Responsibility. } \\
\text { Best-in-class of its reference } \\
\text { universe. } \\
\text { General exclusion criteria and } \\
\text { controversial activities. }\end{array}$ & $\begin{array}{l}6 \text { Key areas. } \\
38 \text { Criteria. } \\
330 \text { Indicators. }\end{array}$ & $\begin{array}{c}\checkmark \\
\text { Equitics Methodology. }\end{array}$ & $\begin{array}{l}\text { Euronext is responsible for monitoring the selection } \\
\text { of constituents for the index and ensuring that the } \\
\text { index offers a reliable and representative view of the } \\
\text { market. }\end{array}$ & $\begin{array}{l}\text { Weight: corporate score divided } \\
\text { by the total sum of the scores of } \\
\text { all companies. }\end{array}$ \\
\hline $\begin{array}{l}\text { FTSE4Good } \\
\text { Developed Index. }\end{array}$ & $\begin{array}{l}\text { General and sectoral ESG } \\
\text { indicators, aligned with SGDs. } \\
\text { Exclusion for controversial } \\
\text { activities. }\end{array}$ & $\begin{array}{l}3 \text { ESG Pillars. } \\
14 \text { ES Themes. } \\
300+\text { Indicators; } 125 \text { average } \\
\text { indicators per company; } \\
\text { each Theme containing } 10 \text { to } \\
35 \text { indicators. }\end{array}$ & $\checkmark$ & $\begin{array}{l}\text { FTSE Russell ESG Advisory Committee (leading } \\
\text { global ressponsible investment market practitioners, } \\
\text { academics, NGOs, inter-governmental } \\
\text { organizations, companies and trade unions) } \\
\text { provides guidance on the criteria and construction } \\
\text { of the index. }\end{array}$ & Weight: Overall ESG Rating. \\
\hline GCX. & $\begin{array}{l}\text { General and sectoral } \\
\text { sustainability indicators. } \\
\text { Best-in-class. } \\
\text { General exclusion }\end{array}$ & $\begin{array}{l}7 \text { Global Challenges (for } \\
\text { each Global Challenge there } \\
\text { are positive criteria and } \\
\text { exclusion criteria). }\end{array}$ & $\approx$ & $\begin{array}{l}\text { An independent advisory board advises in advising } \\
\text { on the development of the index, on the monitoring } \\
\text { of the criteria, and advising on the selection of } \\
\text { suitable companies for the index. }\end{array}$ & Weight. \\
\hline $\begin{array}{l}\text { Global CR RepTrak } \\
100 .\end{array}$ & $\begin{array}{l}\text { General sustainability indicators } \\
\text { common to all companies. }\end{array}$ & $\begin{array}{l}3 \text { Dimensions. } \\
9 \text { Attributes. }\end{array}$ & CR RepTrak Pulse Methodology. & Not specified. & $\begin{array}{l}\text { Score: } 0-100 . \\
\text { Qualification: score is grouped } \\
\text { into } 5 \text { performance bands } \rightarrow \\
\text { Excellent }(80+) \text {; Strong }(70-79) ; \\
\text { Average }(60-69) ; \text { Weak }(40-59) ; \\
\text { and Poor }(0-39) \text {. }\end{array}$ \\
\hline
\end{tabular}


Table A3. Cont.

\begin{tabular}{|c|c|c|c|c|c|}
\hline CSS & Selection \& Exclusion Criterion & Number of Criteria Used & Use of Their Own Methodology & The Evaluation Process has External Verification & Unit of Scoring or Qualification \\
\hline GSLI. & $\begin{array}{l}\text { General and sectoral ESG } \\
\text { indicators. } \\
\text { General exclusion. } \\
\text { Signatories of the UN Global } \\
\text { Compact and to comply with the } \\
\text { Principles. }\end{array}$ & $\begin{array}{l}3 \text { ESG Dimensions. } \\
10 \text { Principles of the UN } \\
\text { Global Compact. }\end{array}$ & $\checkmark$ & Not specified. & Weight. \\
\hline $\begin{array}{l}\text { ISS-oekom Corporate } \\
\text { Rating. }\end{array}$ & $\begin{array}{l}\text { ESG indicators cross-sectoral and } \\
\text { sector-specific, aligned with } \\
\text { SDGs. } \\
\text { Best-in-class: Industry Leaders. } \\
\text { Exclusion criteria: analysis of } \\
\text { relevant Controversies. }\end{array}$ & $\begin{array}{l}2 \text { Dimensions. } \\
\text { 30+ ESG Topics } \\
\text { cross-sectoral. } \\
800+\text { Detailed } \\
\text { Industry-Specific Criteria; } \\
\text { each company is assessed } \\
\text { against approximately } 100 \\
\text { individual indication. }\end{array}$ & $\checkmark$ & $\begin{array}{l}\text { An International Methodology Board ensures a high } \\
\text { quality analyses, indicators, rating structures and } \\
\text { results. } \\
\text { An External Rating Committee (formed by ESG } \\
\text { experts) supports in the design of industry-specific } \\
\text { criteria and carries out a final check of the results. }\end{array}$ & $\begin{array}{l}\text { Score: Overall Score, } 0-100 . \\
\text { Qualification: Corporate } \\
\text { Sustainability Rating, score is } \\
\text { grouped into } 12 \text { performance } \\
\text { bands } \rightarrow \text { A+/A/ A- (Excellent, } \\
3.25-4.00) ; \mathrm{B}+/ \mathrm{B} / \mathrm{B}-(\text { Good, } \\
2.50-<3.25) ; \mathrm{C}+/ \mathrm{C} / \mathrm{C}-(\text { Medium, } \\
1.75-<2.50 \text { ); and D+/D/ D- (Poor; } \\
1.00-<1.75 \text { ). }\end{array}$ \\
\hline $\begin{array}{l}\text { MSCI World ESG } \\
\text { Leaders Index. }\end{array}$ & $\begin{array}{l}\text { General and sectoral } \\
\text { sustainability indicators. } \\
\text { Best-in-class: selecting } \\
\text { companies that have the highest } \\
\text { MSCI ESG Ratings. } \\
\text { General exclusion. }\end{array}$ & $\begin{array}{l}\text { 3 ESG Pillars. } \\
10 \text { ESG Themes. } \\
37 \text { ESG Key Issues. } \\
1000+\text { data points on ESG } \\
\text { policies, programs and } \\
\text { performance. } \\
\text { 600 Policy/Programs } \\
\text { Metrics, 240 Performance } \\
\text { Metrics and } 96 \text { Governance } \\
\text { Key Metrics. }\end{array}$ & MSCI FaCS Methodology. & $\begin{array}{l}\text { Methodology Committee approval of any } \\
\text { exceptions, truncations, or major rating changes. } \\
\text { ESG Methodology Committee to review } \\
\text { contentious cases. }\end{array}$ & $\begin{array}{l}\text { Weight: ESG Rating, weighted } \\
\text { averages of key issue scores and } \\
\text { weighted by activity sector. } \\
\text { Qualification: MSCI ESG Ratings, } \\
\text { score is grouped into } 7 \\
\text { performance bands } \rightarrow \text { AAA } \\
(8.6-10.0) ; \text { AA (7.1-8.6); A } \\
(5.7-7.1) \text {; BBB (4.3-5.7); BB } \\
(2.9-4.3) \text {; B (1.4-2.9); and CCC } \\
(0.0-1.4) \text {. }\end{array}$ \\
\hline $\begin{array}{l}\text { STOXX Global ESG } \\
\text { Leaders Index. }\end{array}$ & $\begin{array}{l}\text { General and sectoral ESG } \\
\text { indicators. } \\
\text { Best-in-class. } \\
\text { General exclusion. }\end{array}$ & $\begin{array}{l}3 \text { ESG Dimensions. } \\
134 \text { KPIs. }\end{array}$ & $\checkmark$ & $\begin{array}{l}\text { The model has been mapped to the "KPIs for ESG } \\
\text { 3.0" standard defined by Deutsche Vereinigung für } \\
\text { Finanzanalyse und Asset Management (DVFA). } \\
\text { An independent advisory committee gives advice } \\
\text { on the general ESG methodology. }\end{array}$ & $\begin{array}{l}\text { Weight: price-weighted with a } \\
\text { weighting factor. } \\
\text { Score: ESG Score, } 0-100 .\end{array}$ \\
\hline Supplier CSR Rating. & $\begin{array}{l}\text { General sustainability indicators } \\
\text { and Management System } \\
\text { implemented in a company. }\end{array}$ & $\begin{array}{l}4 \text { Themes. } \\
21 \text { CSR Criteria. } \\
3 \text { Management Layers } \\
\text { (components of an effective } \\
\text { CSR Management Systems). } \\
7 \text { Management Indicators. }\end{array}$ & $\checkmark$ & $\begin{array}{l}\text { The methodology is reviewed by an External } \\
\text { Committee made up of scientists and other CSR } \\
\text { experts; and it is audited by PwC. }\end{array}$ & $\begin{array}{l}\text { Score: Overall Score, } 0-100 . \\
\text { Qualification: CSR Rating, score } \\
\text { is grouped into } 3 \text { performance } \\
\text { bands } \rightarrow \text { Gold ( } 62-100) \text {; Silver } \\
\text { (46-61); and Bronze (37-45). } \\
\text { Qualification: CSR } \\
\text { Performance/Scoring Scale, score } \\
\text { is grouped into } 5 \text { performance } \\
\text { bands } \rightarrow \text { Outsanding (85-100); } \\
\text { Advanced (65-84); Confirmed } \\
\text { (45-64); Partial (25-44); and } \\
\text { None (0-24). }\end{array}$ \\
\hline
\end{tabular}


Table A3. Cont.

\begin{tabular}{|c|c|c|c|c|c|}
\hline CSS & Selection \& Exclusion Criterion & Number of Criteria Used & Use of Their Own Methodology & The Evaluation Process has External Verification & Unit of Scoring or Qualification \\
\hline $\begin{array}{l}\text { Sustainalytics' ESG } \\
\text { Risk Rating. }\end{array}$ & $\begin{array}{l}\text { General and sectoral ESG } \\
\text { indicators. } \\
\text { Best-in-class. } \\
\text { Disagreements measurement. } \\
\text { Controversy analysis. }\end{array}$ & $\begin{array}{l}3 \text { Central Building Blocks. } \\
20 \text { Material ESG Issues } \\
\text { (MEIs); } 10 \text { MEIs per } \\
\text { Sub-industry. } \\
40 \text { Industry-specific } \\
\text { indicators approx. } \\
\text { Criteria (the number is not } \\
\text { specified). }\end{array}$ & ESG Risk Rating Methodology. & Not specified. & $\begin{array}{l}\text { Score: Overall ESG Risk Rating } \\
\text { Score, } 0-100 . \\
\text { Qualification: ESG Risk } \\
\text { Categories, score is grouped into } \\
5 \text { performance bands } \rightarrow \\
\text { Negligible Risk (0-9.99); Low } \\
\text { Risk (10-19.99); Medium Risk } \\
\text { (20-29.99); High Risk (30-39.99); } \\
\text { and Severe Risk (40-100). }\end{array}$ \\
\hline $\begin{array}{l}\text { The Sustainability } \\
\text { Yearbook. }\end{array}$ & $\begin{array}{l}\text { General and sectoral ESG } \\
\text { indicators. } \\
\text { Best-in-class. } \\
\text { Ethical exclusion of controversial } \\
\text { sectors. }\end{array}$ & $\begin{array}{l}3 \text { Dimensions. } \\
68 \text { Criterions. } \\
80-100 \text { industry-specific } \\
\text { questions. } \\
60 \text { industry-specific issues; } \\
\text { cover } 20 \text { different key } \\
\text { themes. }\end{array}$ & $\begin{array}{l}\checkmark \\
\text { Corporate Sustainability } \\
\text { Assessment (CSA). }\end{array}$ & $\begin{array}{l}\text { The evaluation process is verified every year by } \\
\text { Deloitte. }\end{array}$ & $\begin{array}{l}\text { Score: Total Sustainability Score } \\
\text { (TSS), 0-100. } \\
\text { Qualification: SAM Class } \\
\text { Distinction, score is grouped into } \\
4 \text { performance bands } \rightarrow \text { Gold } \\
\text { Class (60+); Silver Class (57-59); } \\
\text { Bronze Class (54-56); Member } \\
\text { (54-). }\end{array}$ \\
\hline $\begin{array}{l}\text { World's Most } \\
\text { Sustainable } \\
\text { Corporations-Global } \\
100 .\end{array}$ & $\begin{array}{l}\text { Universal and priority } \\
\text { sustainability KPIs. } \\
\text { Best-in-class. } \\
\text { General exclusion. }\end{array}$ & $\begin{array}{l}5 \text { Dimensions. } \\
21 \text { KPIs: } 13 \text { Priority KPIs } \\
\text { and } 8 \text { Universal KPIs. }\end{array}$ & $\checkmark$ & $\begin{array}{l}\text { A panel of sustainability professionals is in charge } \\
\text { of reviewing the methodology. } \\
\text { CK verifies public information through direct } \\
\text { contact with companies. }\end{array}$ & Score: Overall Score, $0-100 \%$. \\
\hline
\end{tabular}


Table A4. Block 4: Criteria for describing the companies sample that constitute the Initial Universe and the Final Universe of the CSSs.

\begin{tabular}{|c|c|c|c|c|c|c|c|c|c|}
\hline \multirow[b]{2}{*}{ CSS } & \multirow{2}{*}{$\begin{array}{l}\text { Number of } \\
\text { Companies in the } \\
\text { Final List }\end{array}$} & \multirow{2}{*}{$\begin{array}{l}\text { Sectorial Classification } \\
\text { System used }\end{array}$} & \multirow{2}{*}{$\begin{array}{l}\text { Comparability Between } \\
\text { Companies }\end{array}$} & \multicolumn{3}{|c|}{ Initial Universe } & \multicolumn{3}{|c|}{ Final Universe } \\
\hline & & & & $\begin{array}{l}\text { Number of } \\
\text { Companies }\end{array}$ & $\begin{array}{l}\text { Number of } \\
\text { Countries }\end{array}$ & $\begin{array}{l}\text { Number of } \\
\text { Sectors }\end{array}$ & $\begin{array}{l}\text { Number of } \\
\text { Companies }\end{array}$ & $\begin{array}{l}\text { Number of } \\
\text { Countries }\end{array}$ & $\begin{array}{l}\text { Number of } \\
\text { Sectors }\end{array}$ \\
\hline DJSI World. & Variable. & $\begin{array}{l}\text { Own sector classification } \\
\text { system: SAM Industry } \\
\text { Classification with } 62 \\
\text { SAM Industries; based on } \\
\text { the "Industry Group" and } \\
\text { "Sector" level of GICS. }\end{array}$ & $\begin{array}{l}\text { The index is } \\
\text { multi-sectoral, although it } \\
\text { differentiates sectors. }\end{array}$ & $\begin{array}{l}3503 \text { invited to the } \\
\text { CSA process. } \\
2500 \text { in the } \\
\text { Eligible Universe. }\end{array}$ & 48. & $\begin{array}{l}62 \mathrm{SAM} \\
\text { Industries. }\end{array}$ & 317. & 29. & 24. \\
\hline $\begin{array}{l}\text { ECPI World ESG } \\
\text { Equity Index. }\end{array}$ & Variable. & GICS: "Sector" level. & $\begin{array}{l}\text { The index is } \\
\text { multi-sectoral, although it } \\
\text { differentiates sectors. }\end{array}$ & Not specified. & 25. & 11 Sectors. & 1,661 . & Not specified. & 11. \\
\hline $\begin{array}{l}\text { ESI Excellence } \\
\text { Global. }\end{array}$ & Variable. & $\begin{array}{l}\text { ICB: "Supersector" or } \\
\text { "Industry" level } \\
\text { (depending on year). }\end{array}$ & $\begin{array}{l}\text { The classification is } \\
\text { multi-sectoral, no } \\
\text { differentiation between } \\
\text { sectors. }\end{array}$ & Not specified. & Not specified. & Not specified. & 88. & Not specified. & Not specified \\
\hline $\begin{array}{l}\text { Euronext Vigeo } \\
\text { Eiris World } 120 .\end{array}$ & Stationary: 120. & $\begin{array}{l}\text { Own sector classification } \\
\text { system: "Sector" level. }\end{array}$ & $\begin{array}{l}\text { The classification is } \\
\text { multi-sectoral, although it } \\
\text { differentiates sectors. }\end{array}$ & 1500 approx. & Not specified. & Not specified. & 120. & 17. & 26. \\
\hline $\begin{array}{l}\text { FTSE4Good } \\
\text { Developed Index. }\end{array}$ & Variable. & ICB: "Supersector" level. & $\begin{array}{l}\text { The index is } \\
\text { multi-sectoral, although it } \\
\text { differentiates sectors. }\end{array}$ & 5000 approx. & 47. & $\begin{array}{l}19 \\
\text { Supersectors. }\end{array}$ & 941. & 24. & 19. \\
\hline $\mathrm{GCX}^{1}$. & Stationary: 50. & $\begin{array}{l}\text { Own sector classification } \\
\text { system: "Industry" level. }\end{array}$ & $\begin{array}{l}\text { The classification is } \\
\text { multi-sectoral, although it } \\
\text { differentiates sectors. }\end{array}$ & 3800 approx. & Not specified. & Not specified. & 50. & 14. & 30. \\
\hline $\begin{array}{l}\text { Global CR } \\
\text { RepTrak 100. }\end{array}$ & Stationary: 100. & $\begin{array}{l}\text { Own sector classification } \\
\text { system: "Industry" level } \\
\text { (varies annually) }{ }^{2} \text {. }\end{array}$ & $\begin{array}{l}\text { The classification is } \\
\text { multi-sectorial, no } \\
\text { differentiation between } \\
\text { sectors. }\end{array}$ & $7000+$ & 40. & 25 Industries. & 100. & $16^{5}$. & Not specified \\
\hline GSLI. & Variable. & $\begin{array}{l}\text { Sector classification } \\
\text { system: "Sector" level (the } \\
\text { CSS does not specify } \\
\text { whether it is its own or } \\
\text { based on an international } \\
\text { standard). }\end{array}$ & $\begin{array}{l}\text { The index is } \\
\text { multi-sectoral, although it } \\
\text { differentiates sectors. }\end{array}$ & $7500+$. & Not specified. & Not specified. & 100. & Not specified. & 10. \\
\hline $\begin{array}{l}\text { ISS-oekom } \\
\text { Corporate Rating. }\end{array}$ & Variable. & $\begin{array}{l}\text { Sector classification } \\
\text { system: "Sector" level (the } \\
\text { CSS does not specify } \\
\text { whether it is its own or } \\
\text { based on an international } \\
\text { standard). }\end{array}$ & $\begin{array}{l}\text { The qualifications are } \\
\text { multi-sectoral, but in the } \\
\text { annual report the } \\
\text { qualifications are grouped } \\
\text { by Sector. }\end{array}$ & $\begin{array}{l}3800 \text { approx. } \\
\text { Two partial } \\
\text { research } \\
\text { universes: } 1600 \\
\text { large companies } \\
\text { of DMU; } 800 \text { large } \\
\text { companies of } \\
\text { EMU. }\end{array}$ & 52. & Not specified. & 81 approx. & 16. & 27. \\
\hline
\end{tabular}


Table A4. Cont.

\begin{tabular}{|c|c|c|c|c|c|c|c|c|c|}
\hline \multirow[b]{2}{*}{ CSS } & \multirow{2}{*}{$\begin{array}{l}\text { Number of } \\
\text { Companies in the } \\
\text { Final List }\end{array}$} & \multirow{2}{*}{$\begin{array}{l}\text { Sectorial Classification } \\
\text { System used }\end{array}$} & \multirow{2}{*}{$\begin{array}{l}\text { Comparability Between } \\
\text { Companies }\end{array}$} & \multicolumn{3}{|c|}{ Initial Universe } & \multicolumn{3}{|c|}{ Final Universe } \\
\hline & & & & $\begin{array}{l}\text { Number of } \\
\text { Companies }\end{array}$ & $\begin{array}{l}\text { Number of } \\
\text { Countries }\end{array}$ & $\begin{array}{l}\text { Number of } \\
\text { Sectors }\end{array}$ & $\begin{array}{l}\text { Number of } \\
\text { Companies }\end{array}$ & $\begin{array}{l}\text { Number of } \\
\text { Countries }\end{array}$ & $\begin{array}{l}\text { Number of } \\
\text { Sectors }\end{array}$ \\
\hline $\begin{array}{l}\text { MSCI World ESG } \\
\text { Leaders Index. }\end{array}$ & Variable. & GICS: “Sector” level. & $\begin{array}{l}\text { The index is } \\
\text { multi-sectoral, although it } \\
\text { differentiates sectors. }\end{array}$ & 1635. & 23. & 11 Sectors. & 829. & Not specified. & 11. \\
\hline $\begin{array}{l}\text { STOXX Global } \\
\text { ESG Leaders } \\
\text { Index. }\end{array}$ & Variable. & $\begin{array}{l}\text { Own sector classification } \\
\text { system: "Industry Group" } \\
\text { level in the Initial } \\
\text { Universe, and } \\
\text { "Supersector" level in the } \\
\text { Final Sample. }\end{array}$ & $\begin{array}{l}\text { The index is } \\
\text { multi-sectoral, although it } \\
\text { differentiates sectors. }\end{array}$ & 1800. & 24. & $\begin{array}{l}42 \\
\text { Supersectors. }\end{array}$ & 396. & 22. & 19. \\
\hline $\begin{array}{l}\text { Supplier CSR } \\
\text { Rating. }\end{array}$ & Variable. & Not specified. & Not specified. & $\begin{array}{l}\text { 42,000 approx.: } \\
30,000 \text { suppliers } \\
\text { (70.00\% SMEs) y } \\
12,000 \text { buyers ( } 170 \\
\text { multinationals). }\end{array}$ & $150+$ & $\begin{array}{l}190 \text { Industrial } \\
\text { Sectors. }\end{array}$ & Not specified. & Not specified. & Not specified. \\
\hline $\begin{array}{l}\text { Sustainalytics' } \\
\text { ESG Risk Rating. }\end{array}$ & Variable. & $\begin{array}{l}\text { Own sector classification } \\
\text { system: "Sub-industry" } \\
\text { level (based on } \\
\text { internationally accepted } \\
\text { standards, not specified), } \\
\text { with } 42 \text { industries and } 139 \\
\text { sub-industries. }\end{array}$ & Not specified. & 11,000 approx. & Not specified. & $\begin{array}{l}139 \\
\text { sub-industries. }\end{array}$ & Not specified. & Not specified. & Not specified. \\
\hline $\begin{array}{l}\text { The Sustainability } \\
\text { Yearbook. }\end{array}$ & Variable. & $\begin{array}{l}\text { Own sector classification } \\
\text { system: SAM Industry } \\
\text { Classification with } 62 \\
\text { SAM Industries; based on } \\
\text { the "Industry Group" and } \\
\text { "Sector" level of GICS. }\end{array}$ & $\begin{array}{l}\text { The qualifications are } \\
\text { multi-sectorial, but in the } \\
\text { annual report the } \\
\text { qualifications are grouped } \\
\text { by SAM Industry. }\end{array}$ & $\begin{array}{l}3517 \text { invited to the } \\
\text { CSA process. } \\
2687 \text { were } \\
\text { assessed in the } \\
\text { CSA. }\end{array}$ & $\begin{array}{l}47 . \\
44 .\end{array}$ & $\begin{array}{l}60 \text { SAM } \\
\text { Industries. }\end{array}$ & 458. & 36. & 60. \\
\hline $\begin{array}{l}\text { World's Most } \\
\text { Sustainable } \\
\text { Corporations-Global } \\
100 .\end{array}$ & Stationary: 100. & $\begin{array}{l}\text { Own sector classification } \\
\text { system: Corporate } \\
\text { Knights Industry Group } \\
\text { (CKIG) with "Industry" } \\
\text { level; based on GICS. }\end{array}$ & $\begin{array}{l}\text { The classification is } \\
\text { multi-sectorial, although it } \\
\text { differentiates sectors. }\end{array}$ & $\begin{array}{l}5994 \text { in the } \\
\text { Eligible Universe. }\end{array}$ & Not specified $^{3}$. & Not specified ${ }^{4}$. & 100. & 21. & 41. \\
\hline
\end{tabular}

Notes: ${ }^{1}$ There is a middle stage with 375 companies approx., after the phase carried out by ISS-oekom. ${ }^{2}$ The 2017 report (“2017 Global CSR RepTrak: Reputation and Corporate Social Responsibility") is the last time the CSS differentiates industries (12 Industries). ${ }^{3}$ Companies by country of origin are not discarded. ${ }^{4}$ Companies by industrial activity are not discarded. ${ }^{5}$ Not specified, this data has been estimated from the final classification of the CSS. 
Table A5. Block 5: Criteria that allow stakeholders to know the public information provided by the CSSs' managers.

\begin{tabular}{|c|c|c|c|c|c|c|}
\hline CSS & $\begin{array}{l}\text { How Information is Obtained for the } \\
\text { Evaluation Process }\end{array}$ & Methodology is Public & Qualifications are Public & $\begin{array}{l}\text { Results of the Evaluation } \\
\text { Process Shown }\end{array}$ & Renewal Periods & $\begin{array}{l}\text { CSS's Manager Provides } \\
\text { an Award Label }\end{array}$ \\
\hline DJSI World. & $\begin{array}{l}\text { Publically available information. } \\
\text { Information of RobecoSAM CSA } \\
\text { process. }\end{array}$ & $\checkmark$ & $\underset{\text { Only constituents }}{\approx}$ & $\begin{array}{l}\text { Index factsheet, downloadable in } \\
\text { the CSS's website. In this } \\
\text { document only is shown the Top } \\
10 \text { Constituents, without } \\
\text { specifying the weights. } \\
\text { RobecoSAM and S\&P Dow Jones } \\
\text { Indices also provides a document } \\
\text { where the index constituents are } \\
\text { shown, but without specifying } \\
\text { the weights. }\end{array}$ & $\begin{array}{l}\text { The CSA process is } \\
\text { updated annually and } \\
\text { the process lasts six } \\
\text { months: the process } \\
\text { begins in March, the } \\
\text { new scores and new } \\
\text { index composition } \\
\text { released in September. } \\
\text { Index calculation } \\
\text { frequency in real time. }\end{array}$ & The DJSI Member logo. \\
\hline $\begin{array}{l}\text { ECPI World ESG } \\
\text { Equity Index. }\end{array}$ & $\begin{array}{l}\text { Publicly-available sources: annual } \\
\text { reports, sustainability reports, } \\
\text { environmental reports or CSR reports } \\
\text { of the companies; company websites; } \\
\text { regulatory data; information providers } \\
\text { and search engines; media and news } \\
\text { services; Bloomberg and Thomson } \\
\text { Reuters; thematic websites promoted } \\
\text { by NGOs; Company Investor Relations } \\
\text { departments, when necessary; national } \\
\text { and international university networks. }\end{array}$ & $\checkmark$ & $\begin{array}{c}\checkmark \\
\text { Constituents and weights }\end{array}$ & $\begin{array}{l}\text { Index factsheet, downloadable in } \\
\text { the CSS's website. In this } \\
\text { document only is shown the Top } \\
10 \text { Constituents, with the weights } \\
\text { of the companies. } \\
\text { ECPI provides a document where } \\
\text { the index constituents are shown, } \\
\text { with the weights of the } \\
\text { companies. }\end{array}$ & $\begin{array}{l}\text { Every three months the } \\
\text { index constituents are } \\
\text { reviewed: March, June, } \\
\text { September and } \\
\text { December. } \\
\text { The index is calculated } \\
\text { and published daily. }\end{array}$ & \\
\hline ESI Excellence Global. & $\begin{array}{l}\text { Vigeo Eiris provides the results of his } \\
\text { research: data collecting and } \\
\text { processing. }\end{array}$ & $\checkmark$ & $\begin{array}{c}\checkmark \\
\text { Constituents and weights }\end{array}$ & $\begin{array}{l}\text { Index factsheet, downloadable in } \\
\text { the CSS's website. In this } \\
\text { document the index constituents } \\
\text { are shown, specifying the } \\
\text { weights. }\end{array}$ & $\begin{array}{l}\text { The index composition } \\
\text { is reviewed } \\
\text { semi-annually: March } \\
\text { and September. } \\
\text { Re-assessment of the } \\
\text { CSR profile of } \\
\text { companies are } \\
\text { executed every } 18 \\
\text { months. } \\
\text { Index calculation } \\
\text { frequency in real time. }\end{array}$ & $\begin{array}{l}\text { Ethibel PIONEER and } \\
\text { EXCELLENCE Investment } \\
\text { Register. } \\
\text { Included in Ethibel } \\
\text { Sustainability Index } \\
\text { EXCELLENCE Global. }\end{array}$ \\
\hline $\begin{array}{l}\text { Euronext Vigeo Eiris } \\
\text { World } 120 .\end{array}$ & Not specified. & $\checkmark$ & $\underset{\text { Only constituents }}{\approx}$ & $\begin{array}{l}\text { Index factsheet, downloadable in } \\
\text { the CSS's website. In this } \\
\text { document the index constituents } \\
\text { are shown, without specifying the } \\
\text { weights. }\end{array}$ & $\begin{array}{l}\text { The index composition } \\
\text { is reviewed } \\
\text { semi-annually: May } \\
\text { and November. } \\
\text { The index is calculated } \\
\text { daily. }\end{array}$ & \\
\hline
\end{tabular}


Table A5. Cont.

\begin{tabular}{|c|c|c|c|c|c|c|}
\hline CSS & $\begin{array}{l}\text { How Information is Obtained for the } \\
\text { Evaluation Process }\end{array}$ & Methodology is Public & Qualifications are Public & $\begin{array}{l}\text { Results of the Evaluation } \\
\text { Process Shown }\end{array}$ & Renewal Periods & $\begin{array}{l}\text { CSS's Manager Provide } \\
\text { an Award Label }\end{array}$ \\
\hline $\begin{array}{l}\text { FTSE4Good } \\
\text { Developed Index. }\end{array}$ & $\begin{array}{l}\text { Information collected through public } \\
\text { sources: voluntary sustainability } \\
\text { reports, mandatory accounting } \\
\text { disclosures, regulatory filings, media } \\
\text { NGOs, stock exchanges... } \\
\text { Every company is individually } \\
\text { contacted to check the publicly } \\
\text { information, but no privately } \\
\text { submitted information is accepted. }\end{array}$ & & & $\begin{array}{l}\text { Index factsheet, downloadable in } \\
\text { the CSS's website. In this } \\
\text { document only is shown the Top } \\
10 \text { Constituents, with the weights } \\
\text { of the companies. }\end{array}$ & $\begin{array}{l}\text { The index is reviewed } \\
\text { semi-annually: June } \\
\text { and December. } \\
\text { The index is calculated } \\
\text { real time and } \\
\text { end-of-day. }\end{array}$ & \\
\hline GCX. & $\begin{array}{l}\text { The ISS-oekom evaluation is used in } \\
\text { the first stage of the methodology }\end{array}$ & $\checkmark$ & $\underset{\text { Only constituents }}{\approx}$ & $\begin{array}{l}\text { Annual report (Factbook), } \\
\text { downloadable in the CSS's } \\
\text { website. In this document are } \\
\text { shown the index components, } \\
\text { without specifying the weights. }\end{array}$ & $\begin{array}{l}\text { The composition of the } \\
\text { index is reviewed } \\
\text { semi-annually: March } \\
\text { and September. }\end{array}$ & \\
\hline $\begin{array}{l}\text { Global CR RepTrak } \\
100 .\end{array}$ & $\begin{array}{l}\text { Surveys of general public from } 15 \\
\text { countries: Australia, Brazil, Canada, } \\
\text { China, France, Germany, India, Italy, } \\
\text { Japan, Mexico, Russia, South Korea, } \\
\text { Spain, United Kingdom and United } \\
\text { States. }\end{array}$ & & $\stackrel{\checkmark}{\text { Constituents and scores }}$ & $\begin{array}{l}\text { Annual Report, downloadable in } \\
\text { the CSS's website. In this } \\
\text { document is shown the ranking } \\
\text { with the } 100 \text { companies with the } \\
\text { best score. }\end{array}$ & $\begin{array}{l}\text { The annual report is } \\
\text { published in October. } \\
\text { The Ranking is } \\
\text { updated annually, and } \\
\text { the process lasts two } \\
\text { months: January and } \\
\text { February. }\end{array}$ & \\
\hline GSLI. & Not specified. & & & $\begin{array}{l}\text { Index factsheet, downloadable in } \\
\text { the CSS's website. In this } \\
\text { document only is shown the Top } \\
10 \text { Constituents, with the weights } \\
\text { of the companies. }\end{array}$ & $\begin{array}{l}\text { The index allocation is } \\
\text { reviewed annually. } \\
\text { The index is weighted } \\
\text { quarterly: March, June } \\
\text { and December. }\end{array}$ & \\
\hline $\begin{array}{l}\text { ISS-oekom Corporate } \\
\text { Rating. }\end{array}$ & $\begin{array}{l}\text { The information is collected from } \\
\text { public sources (e.g., international } \\
\text { media), from interviews with } \\
\text { independent experts in corporate } \\
\text { sustainability (e.g., international NGOs } \\
\text { and scientific institutions) and from the } \\
\text { companies evaluated (e.g., annual } \\
\text { report, CSR report and website). } \\
\text { During the evaluation process there is a } \\
\text { feedback with the companies evaluated, } \\
\text { so that the companies can comment } \\
\text { and add information. }\end{array}$ & $\checkmark$ & & $\begin{array}{l}\text { A full rating report is delivered to } \\
\text { the company; providing a } \\
\text { qualitative summary and analysis } \\
\text { of rating results. } \\
\text { Part of the results are shown on } \\
\text { an annual report, "oekom } \\
\text { Corporate Responsibility Review, } \\
\text { downloadable in the CSS's } \\
\text { website. This document shows } \\
\text { the Top } 3 \text { for each Sector. }\end{array}$ & $\begin{array}{l}\text { The annual report is } \\
\text { published in March or } \\
\text { April. } \\
\text { Company information } \\
\text { is renewed annually. } \\
\text { Indicators are regularly } \\
\text { reviewed. }\end{array}$ & Prime Status. \\
\hline
\end{tabular}


Table A5. Cont.

\begin{tabular}{|c|c|c|c|c|c|c|}
\hline CSS & $\begin{array}{l}\text { How Information is Obtained for the } \\
\text { Evaluation Process }\end{array}$ & Methodology is Public & Qualifications are Public & $\begin{array}{l}\text { Results of the Evaluation } \\
\text { Process Shown }\end{array}$ & Renewal Periods & $\begin{array}{l}\text { CSS's Manager Provides } \\
\text { an Award Label }\end{array}$ \\
\hline $\begin{array}{l}\text { MSCI World ESG } \\
\text { Leaders Index. }\end{array}$ & $\begin{array}{l}\text { The data is collected from academic, } \\
\text { government, NGO datasets; company } \\
\text { disclosure (e.g., sustainability report); } \\
\text { and government databases (media, } \\
\text { NGO, other stakeholders, sources } \\
\text { regarding specific companies). } \\
\text { Companies are invited to participate in } \\
\text { a formal data verification process prior } \\
\text { to publication of their ESG Ratings } \\
\text { report; companies may provide } \\
\text { additional ESG information. }\end{array}$ & $\checkmark$ & & $\begin{array}{l}\text { Index factsheet, downloadable in } \\
\text { the CSS's website. In this } \\
\text { document only is shown the Top } \\
10 \text { Constituents, with the weights } \\
\text { of the companies. } \\
\text { MSCI ESG Ratings clients receive } \\
\text { access to a database of company } \\
\text { reports and industry reports } \\
\text { (MSCI ESG Research's } \\
\text { proprietary platform). }\end{array}$ & $\begin{array}{l}\text { The index composition } \\
\text { is reviewed annually in } \\
\text { May. } \\
\text { The Key Issues } \\
\text { assigned to each } \\
\text { industry and their } \\
\text { weights are reviewed } \\
\text { in November. } \\
\text { Index is rebalanced } \\
\text { quarterly: February, } \\
\text { August and November. }\end{array}$ & \\
\hline $\begin{array}{l}\text { STOXX Global ESG } \\
\text { Leaders Index. }\end{array}$ & $\begin{array}{l}\text { Sustainalytics provides the KPI } \\
\text { information for each company, and the } \\
\text { data necessary for the exclusion of the } \\
\text { companies. } \\
\text { Information from several sources are } \\
\text { revised: company documents (e.g., } \\
\text { updated sustainability reports), reports } \\
\text { from NGOs, specialized databased, } \\
\text { industry newsletter or public interest } \\
\text { group. }\end{array}$ & $\checkmark$ & $\begin{array}{c}\checkmark \\
\text { Constituents and weights }\end{array}$ & $\begin{array}{l}\text { CSS's website. Only are shown } \\
\text { the index components, without } \\
\text { specifying the weights. } \\
\text { In addition, two documents can } \\
\text { be download: Components } \\
\text { Information, are shown the index } \\
\text { components specifying the } \\
\text { weights; and Factsheet document, } \\
\text { only is shown the Top } 10 \\
\text { Constituents with the weights of } \\
\text { the companies. }\end{array}$ & $\begin{array}{l}\text { The index is reviewed } \\
\text { annually in September. } \\
\text { The index is } \\
\text { rebalanced quarterly. } \\
\text { Index calculation } \\
\text { frequency in real time. }\end{array}$ & \\
\hline Supplier CSR Rating. & $\begin{array}{l}\text { Public information provided by } \\
\text { different stakeholders: CDP, trade } \\
\text { unions, international organizations, } \\
\text { local authorities, specialized press and } \\
\text { CSR networks. } \\
\text { Specific questionnaires are sent to each } \\
\text { company, and companies must submit } \\
\text { formal, recent and credible } \\
\text { documentation on the CSR } \\
\text { Management System implemented in } \\
\text { the company. }\end{array}$ & $\checkmark$ & & $\begin{array}{l}\text { Platform on the CSS's website. } \\
\text { These results can be seen by the } \\
\text { evaluated company and by the } \\
\text { buyers or suppliers. } \\
\text { Each evaluated company is sent a } \\
\text { CSR report with the scores and a } \\
\text { summary with the results of the } \\
\text { analysis. }\end{array}$ & $\begin{array}{l}\text { The company's CSR } \\
\text { report is updated } \\
\text { annually and is valid } \\
\text { for twelve months. }\end{array}$ & Gold, Silver and Bronze. \\
\hline
\end{tabular}


Table A5. Cont.

\begin{tabular}{|c|c|c|c|c|c|c|}
\hline CSS & $\begin{array}{l}\text { How Information is Obtained for the } \\
\text { Evaluation Process }\end{array}$ & Methodology is Public & Qualifications are Public & $\begin{array}{l}\text { Results of the Evaluation } \\
\text { Process Shown }\end{array}$ & Renewal Periods & $\begin{array}{l}\text { CSS's Manager Provides } \\
\text { an Award Label }\end{array}$ \\
\hline $\begin{array}{l}\text { Sustainalytics' ESG } \\
\text { Risk Rating. }\end{array}$ & $\begin{array}{l}\text { Information from public sources: } \\
\text { corporate publications (e.g., annual } \\
\text { reports and corporate sustainability } \\
\text { reports); news and other media; NGOs } \\
\text { reports/websites; and multi-sectors } \\
\text { information sources (e.g., GRI, } \\
\text { CDP ... ). } \\
\text { CSS contacts with the companies to } \\
\text { solicit feedback on her research before } \\
\text { the ESG Risk Rating Report is } \\
\text { published. }\end{array}$ & $\checkmark$ & & $\begin{array}{l}\text { Each company receives the } \\
\text { "Sustainalytics ESG Risk Rating } \\
\text { Report" with its evaluation } \\
\text { results, and overall and partial } \\
\text { qualifications and scores. } \\
\text { ESG ratings and assessment } \\
\text { results are available online. }\end{array}$ & $\begin{array}{l}\text { Companies' ESG Risk } \\
\text { Rating is renewed } \\
\text { annually. }\end{array}$ & \\
\hline $\begin{array}{l}\text { The Sustainability } \\
\text { Yearbook. }\end{array}$ & $\begin{array}{l}\text { An industry-specific questionnaire is } \\
\text { sent to each company at the start of the } \\
\text { CSA process; and companies must } \\
\text { submit data to support responses. } \\
\text { Information collected from public } \\
\text { sources. Companies eligible for the } \\
\text { ranking are informed prior to the } \\
\text { ranking, so that to have an opportunity } \\
\text { to ensure the necessary data is made } \\
\text { available publicly. } \\
\text { The controversial sectors analyses are } \\
\text { carried by Sustainalytics. } \\
\text { RepRisk ESG Business Intelligence } \\
\text { provides the results of the Media and } \\
\text { Stakeholder Analysis (MSA) process. }\end{array}$ & $\checkmark$ & $\begin{array}{c}\checkmark \\
\text { Constituents and } \\
\text { qualifications }\end{array}$ & $\begin{array}{l}\text { Annual report, "The } \\
\text { Sustainability Yearbook", } \\
\text { downloadable on the CSS's } \\
\text { website. This document shows } \\
\text { the Gold Class, Silver Class, } \\
\text { Bronze Class, Member and } \\
\text { Industry Mover companies for } \\
\text { each SAM Industry. } \\
\text { Evaluated companies receive } \\
\text { access to an online benchmarking } \\
\text { database, which detailed } \\
\text { performance data. }\end{array}$ & $\begin{array}{l}\text { "The Sustainability } \\
\text { Yearbook" is published } \\
\text { annually in January or } \\
\text { February (year } \\
\text { following CSA } \\
\text { process). } \\
\text { The CSA process is } \\
\text { updated annually and } \\
\text { the process lasts six } \\
\text { months: the process } \\
\text { begins in March and } \\
\text { the new scores released } \\
\text { in September. }\end{array}$ & $\begin{array}{l}\text { Gold Class, Silver Class and } \\
\text { Bronze Class. }\end{array}$ \\
\hline $\begin{array}{l}\text { World's Most } \\
\text { Sustainable } \\
\text { Corporations-Global } \\
100 .\end{array}$ & $\begin{array}{l}\text { Publicly disclosed information (e.g., } \\
\text { sustainability reports). } \\
\text { Companies on the classification are } \\
\text { contacted for data verification. }\end{array}$ & $\checkmark$ & $\begin{array}{c}\checkmark \\
\text { Constituents and scores }\end{array}$ & $\begin{array}{l}\text { CSS's website. There is shown the } \\
\text { ranking with the } 100 \text { companies } \\
\text { with the best Overall Score. }\end{array}$ & $\begin{array}{l}\text { The Ranking is } \\
\text { updated annually in } \\
\text { January. }\end{array}$ & \\
\hline
\end{tabular}




\section{References}

1. Cetindamar, D.; Husoy, K. Corporate social responsibility practices and environmentally responsible behavior: The case of the United Nations global compact. J. Bus. Eth. 2007, 76, 163-176. [CrossRef]

2. Whitehouse, L. Corporate social responsibility, corporate citizenship and the global compact: A new approach to regulating corporate social power? Glob. Soc. Policy 2003, 3, 299-318. [CrossRef]

3. Sach, J.D. From millennium development goals to sustainable development goals. Lancet 2012, 379, $2206-2211$. [CrossRef]

4. Kumar, S.; Kumar, N.; Vivekadhish, S. Millennium Development Goals (MDGs) to Sustainable Development Goals (SDGs): Addresing unfinished agenda and strengthening sustainable development and partnership. Indian J. Community Med. 2016, 41, 1-11. [CrossRef] [PubMed]

5. Martínez-Osés, P.J. Hacer realidad la Agenda: Medios de implementación, revisión y seguimiento. In Transformar nuestro mundo, ¿realidad o ficción?: Reflexiones sobre la Agenda 2030 para el Desarrollo Sostenible. Available online: http://www.unescoetxea.org/dokumentuak/transformar_nuestro_mundo.pdf (accessed on 22 August 2019).

6. Escrig-Olmedo, E.; Muñoz-Torres, M.J.; Fernández-Izquierdo, M.A.; Rivera-Lirio, J.M. Lights and shadows on sustainability rating scoring. Rev. Manag. Sci. 2014, 8, 559-574. [CrossRef]

7. Nizamuddin, M. A study of issues related to selection of corporate social responsibility and firm performance measurement techniques. J. Indian Res. 2017, 5, 60-79.

8. Windolph, S. Assessing corporate sustainability through ratings: Challenges and their causes. J. Environ. Sustain. 2011, 1, 37-57. [CrossRef]

9. Rahdari, A.H.; Anvary-Rostamy, A.A. Designing a general set of sustainability indicators at the corporate level. J. Clean. Prod. 2015, 108, 757-771. [CrossRef]

10. Márquez, A.; Fombrun, C.J. Measuring corporate social responsibility. Corp. Reput. Rev. 2005, 7, $304-308$. [CrossRef]

11. Escrig-Olmedo, E.; Muñoz-Torres, M.J.; Fernández-Izquierdo, M.A. Socially responsible investing: Sustainability indices, ESG rating and information provider agencies. Int. J. Sustain. Econ. 2010, 2, 442-461. [CrossRef]

12. Jankalová, M.; Jankal, R. The assessment of corporate social responsibility: Approaches analysis. Entrep. Sustain. Issues 2017, 4, 441-459. [CrossRef]

13. Mooij, S. The ESG rating and ranking industry; vice or virtue in the adoption of responsible investment? In Smith School of Enterprise and the Environment; Oxford University: Oxford, UK, 2017; pp. 1-75. [CrossRef]

14. Sun, M.; Nagata, K.; Onoda, H. The investigation of the current status of socially responsible investment indices. J. Econ. Int. Financ. 2011, 3, 676-684.

15. Escrig-Olmedo, E.; Fernández-Izquierdo, M.Á.; Ferrero-Ferrero, I.; Rivera-Lirio, J.M.; Muñoz-Torres, M.J. Rating the raters: Evaluating how ESG rating agencies integrate sustainability principles. Sustainability 2019, 11, 915. [CrossRef]

16. Vives, A.; Wadhwa, B. Sustainability indices in emerging markets: Impact on responsible practices and financial market development. J. Sustain. Financ. Invest. 2012, 2, 318-337.

17. Freeman, R.E. Strategic Management: A Stakeholder Approach; Pitman Publishing Inc.: Marshfield, MA, USA, 1984.

18. Fowler, S.J.; Hope, C. A critical review of sustainable business indices and their impact. J. Bus. Eth. 2007, 76, 243-252. [CrossRef]

19. Ching, H.Y.; Toste, T.; Tardelli, R. A reference model of sustainability disclosure based on four sustainability stock indexes. J. Manag. Res. 2016, 8, 44-67. [CrossRef]

20. Charles, A.; Darné, O.; Fouilloux, J. ESG Indices Financial Risk: Performance Measures based on Value-at-Risk Approach; Laboratoire d'Economie et de Management Nantes, Atlantique Université de Nantes (LEMNA): Nantes, France, 2015; pp. 1-28.

21. Fernández-Izquierdo, M.A.; Muñóz-Torres, M.J.; Escrig-Olmedo, E.; Ferrero-Ferrero, I. Sustainability rating agencies as a driver of socially responsible investment. Bol. Estudios Econ. 2018, 73, 367-385.

22. Charles, A.; Darné, O.; Fouilloux, J. The Impact of Screening Strategies on the Performance of ESG Indices; Laboratoire d'Economie et de Management Nantes, Atlantique Université de Nantes (LEMNA): Nantes, France, 2016; pp. 1-32. 
23. World Commission on Environment and Development. Our Common Future (Brundtland Report). 1987. Available online: https://sswm.info/sites/default/files/reference_attachments/UN\%20WCED\%201987\% 20Brundtland\%20Report.pdf (accessed on 22 August 2019).

24. Barkemeyer, R.; Holt, D.; Preuss, L.; Tsang, S. What happened to the 'development' in sustainable development? Business guidelines two decades after brundtland. Sustain. Dev. 2014, 22, 15-32. [CrossRef]

25. Artaraz-Miñón, M. Teoría de las tres dimensiones de desarrollo sostenible. Ecosistemas 2002, 11, 3-6.

26. Friedman, M. Capitalism and Freedom; The University of Chicago Press Ltd.: London, UK, 1962.

27. Danielson, M.G.; Heck, J.L.; Shaffer, D.R. Shareholder theory-How opponents and proponents both get it wrong. J. Appl. Financ. 2008, 18, 62-66. [CrossRef]

28. Freeman, R.E.; Harrison, J.S.; Wicks, A.C.; Parmar, B.L.; de Colle, S. Stakeholder Theory: The State of the Art; Cambridge University Press: New York, NY, USA, 2010.

29. Freeman, R.E.; McVea, J. A stakeholder approach to strategic management. Blackwell Handb. Strateg. Manag. 2005, 183-201. [CrossRef]

30. Freeman, R.E.; Martin, K.; Parmar, B. Stakeholder capitalism. J. Bus. Eth. 2007, 74, 303-314. [CrossRef]

31. Elkington, J. Cannibals with Forks: The Triple Bottom Line of 21st Century Business; Capstone Publishing Ltd.: Oxford, UK, 2007.

32. Mullerat, R. International Corporate Social Responsibility: The Role of Corporations in the Economic Order of the 21st Century; Kluwer Law International: Alphen aan den Rijn, The Netherlands, 2010.

33. Abreu, J.; Badii, M. Analysis of the corporate social responsibility concept. Daena Int. J. Good Conscienc. 2008, 2, 54-70.

34. Bowen, H.R. Social Responsibilities of the Businessman; University of Iowa Press: Iowa City, IA, USA, 2013.

35. Carroll, A.B. Corporate social responsibility: Evolution of a definitional construct. Bus. Soc. 1999, 38, $268-295$. [CrossRef]

36. Frederick, W.C. The growing concern over business responsibility. Calif. Manag. Rev. 1960, 2, 54-61. [CrossRef]

37. McGuire, J.W. Business and Society; McGraw-Hill Book Company Inc.: New York, NY, USA, 1963.

38. Walton, C.C. Corporate social responsibility: The debate revisited. J. Econ. Bus. 1982, 34, 173-187. [CrossRef]

39. Commission of the European Communities. Green Paper: Promoting a European Framework for Corporate Social Responsibility. 2001. Available online: https:/eur-lex.europa.eu/legal-content/EN/TXT/PDF/?uri= CELEX:52001DC0366\&from=EN (accessed on 22 August 2019).

40. International Organization for Standardization (ISO). ISO 26000:2010—Guidance on Social Responsibility: Lignes Directrices Relatives á la Responsabilité Sociétale (First Edition, 2010-11-01). 2010. Available online: http://lastradainternational.org/lsidocs/3078-ISO\%2026000_2010.pdf (accessed on 22 August 2019).

41. Wan-Jan, W. Defining corporate social responsibility. J. Public Aff. 2006, 6, 176-184. [CrossRef]

42. Charlo, M.J.; Moya, I.; Munoz, A.M. Financial performance of socially responsible firms: The short- and long-term impact. Sustainability 2017, 9, 1622. [CrossRef]

43. Boesso, G.; Kumar, K.; Michelon, G. Descriptive, instrumental and strategic approaches to corporate social responsibility: Do they drive the financial performance of companies differently? Account. Audit. Account. J. 2013, 26, 399-422. [CrossRef]

44. Garriga, E.; Melé, D. Corporate social responsibility theories: Mapping the territory. J. Bus. Eth. 2004, 53, 51-71. [CrossRef]

45. Donaldson, T.; Preston, L.E. The stakeholder theory of the corporation-Concepts, evidence, and implications. Acad. Manag. Rev. 1995, 20, 65-91. [CrossRef]

46. Porter, M.E.; Kramer, M.R. The competitive advantage of corporate philanthropy. Harv. Bus. Rev. 2002, 80, 57-68.

47. Carroll, A.B. A three-dimensional conceptual model of corporate performance. AMR 1979, 4, 497-505. [CrossRef]

48. Carroll, A.B. The pyramid of corporate social responsibility: Toward the moral management of organizational stakeholders. Bus. Horiz. 1991, 34, 39-48. [CrossRef]

49. Porter, M.E.; Kramer, M.R. Creating Shared Value. Harv. Bus. Rev. 2011, 89, 62-77. [CrossRef]

50. Aakhus, M.; Bzdak, M. Revisiting the role of "shared value" in the business-society relationship. Bus. Prof. Eth. J. 2012, 31, 231-246. [CrossRef] 
51. Rodríguez-Fernández, J.M. Responsabilidad social corporativa y análisis económico: Práctica frente a teoría. Ekon. Rev. Econ. 2007, 65, 12-49.

52. Sparkes, R. Soc.ly Responsible Investment: A Glob. Revolution; John Wiley \& Sons Ltd.: Chichester, UK, 2002.

53. Jankalová, M. Approaches to the evaluation of corporate social responsibility. Proced. Econ. Financ. 2016, 39, 580-587. [CrossRef]

54. Pope, J.; Annandale, D.; Morrison-Saunders, A. Conceptualising sustainability assessment. Environ. Impact Assess. Rev. 2004, 24, 595-616. [CrossRef]

55. Sparkes, R.; Cowton, C.J. The maturing of socially responsible investment: A review of the developing link with corporate social responsibility. J. Bus. Eth. 2004, 52, 45-57. [CrossRef]

56. United Nations Environment Program (UNEP); UN Global Compact. Principios para la Inversión Responsable: Una Iniciativa de los Inversores en Colaboración con la Iniciativa Financiera del PNUMA y el Pacto Mundial de la ONU. 2019. Available online: https://www.unpri.org/download?ac=6297 (accessed on 22 August 2019).

57. Chatterji, A.K.; Durand, R.; Levine, D.I.; Touboul, S. Do ratings of firms converge? Implications for managers, investors and strategy researchers. Strateg. Manag. J. 2016, 37, 1597-1614. [CrossRef]

58. Galant, A.; Cadez, S. Corporate social responsibility and financial performance relationship: A review of measurement approaches. Econ. Res. Ekon. Istraz. 2017, 30, 676-693. [CrossRef]

59. De Almeida-Joseph, G.P.; Gonçalves-Dias, S.L.F.; Vendramini-Felsberg, A.; Toshiro-Igari, A. Corporate social responsibility and sustainability indexes: A study of tangible and intangible assets under the light of the resource based view. Rev. Gestao Soc. Ambient. 2018, 12, 73-88. [CrossRef]

60. Halkos, G.; Skouloudis, A. Cultural Dimensions and Corporate Social Responsibility: A Cross-Country Analysis; University Library of Munich: Munich, Germany, 2016; pp. 1-33.

61. Consolandi, C.; Jaiswal-Dale, A.; Poggiani, E.; Vercelli, A. Global standards and ethical stock indexes: The case of the dow jones sustainability stoxx index. J. Bus. Eth. 2009, 87, 185-197. [CrossRef]

62. Risalvato, G. Investments in Ethical Funds and Indices: An Overview of Performance; EDIS-Publishing Institution of the University of Zilina: Zilina, Slovakia, 2017; pp. 1-18. [CrossRef]

63. Gjølberg, M. Measuring the immeasurable? Constructing an index of CSR practices and CSR performance in 20 countries. Scand. J. Manag. 2009, 25, 10-22. [CrossRef]

64. Hoti, S.; McAleer, M.; Pauwels, L.L. Modelling environmental risk. Environ. Model. Softw. 2005, 20, $1289-1298$. [CrossRef]

65. Liern, V.; Perez-Gladish, B. Ranking corporate sustainability: A flexible multidimensional approach based on linguistic variables. Int. Trans. Oper. Res. 2018, 25, 1081-1100. [CrossRef]

66. Skouloudis, A.; Isaac, D.; Evaggelinos, K. Revisiting the national corporate social responsibility index. Int. J. Sustain. Dev. World Ecol. 2016, 23, 61-70. [CrossRef]

67. Robinson, M.; Kleffner, A.; Bertels, S. Signaling sustainability leadership: Empirical evidence of the value of DJSI membership. J. Bus. Eth. 2011, 101, 493-505. [CrossRef]

68. Chelli, M.; Gendron, Y. Sustainability ratings and the disciplinary power of the ideology of numbers. J. Bus. Eth. 2013, 112, 187-203. [CrossRef]

69. Ortas, E.; Moneva, J.M. Sustainability stock exchange indexes and investor expectations: Multivariate evidence from DJSI-Stoxx. Rev. Esp. Financ. Contab. Span. J. Financ. Account. 2011, 40, 395-416. [CrossRef]

70. Charlo, M.J.; Moya, I.; Munoz, A.M. Sustainable development and corporate financial performance: A study based on the FTSE4Good IBEX index. Bus. Strateg. Environ. 2015, 24, 277-288. [CrossRef]

71. Finch, N. The emergence of CSR and sustainability indices. Proc. Acad. Account. Financ. Stud. 2006, 11, 19-24. [CrossRef]

72. SustainAbility. Rate the Raters 2019: Expert Views on ESG Ratings. 2019. Available online: https://sustainability. com/wp-content/uploads/2019/02/sustainability-rate-the-raters-2019.pdf (accessed on 22 August 2019).

73. Gnanaweera, K.A.K.; Kunori, N. Corporate sustainability reporting: Linkage of corporate disclosure information and performance indicators. Cogent Bus. Manag. 2018, 5, 1-21. [CrossRef]

74. Börse Hannover. Global Challenges Index Factbook-Version: 28 March 2019. 2019. Available online: http://gcindex.boersenag.de/de/pdf/GCX_Factbook_E_28-03-2019.pdf (accessed on 22 August 2019).

75. Börse Hannover. Global Challenges Index Factsheet as at 20 September 2013. 2013. Available online: http://gcindex.boersenag.de/de/pdf/GCX_Factsheet_EN.pdf (accessed on 22 August 2019). 
76. Corporate Knights. The 2019 Global 100: Overview of Corporate Knights Rating Methodology. 2019. Available online: https://www.corporateknights.com/wp-content/uploads/2018/10/2019-Global-100_ Methodology-Final.pdf?v=20181205 (accessed on 22 August 2019).

77. EcoVadis. EcoVadis CSR Rating Methodology: Overview \& Principles. 2017. Available online: http://help.ecovadis.com/wp-content/uploads/2017/10/EcoVadis_methodology_overview_v2.1_en.pdf (accessed on 22 August 2019).

78. ECPI Group. ECPI World ESG Equity Index Factsheet as of 31 July 2019. 2019. Available online: https://www.ecpigroup.com/wp-content/uploads/factsheet/ECPI_WORLD_ESG_EQUITY.pdf (accessed on 22 August 2019).

79. ECPI Group. Index Rules: ECPI World ESG Equity Index-February 2018. 2018. Available online: https://www.ecpigroup.com/wp-content/uploads/rules/ECPI_World_ESG_Index_INDEX_RULES.pdf (accessed on 22 August 2019).

80. ECPI Group. ECPI ESG Rating Methodology: Equity \& Corporate Bond Issuers-V. 1.6, March 2018. 2018. Available online: https:/www.ecpigroup.com/wp-content/uploads/2019/05/ECPI_ESG_Rating Methodology_Companies.pdf (accessed on 22 August 2019).

81. Euronext. Index Rule Book: Euronext Vigeo Family-Version 17-02, Effective from 1 July 2017. 2017. Available online: http://www.vigeo-eiris.com/wp-content/uploads/2016/11/Euronext-Vigeo-rules-version-1702-Jul-2017.pdf (accessed on 22 August 2019).

82. Euronext Vigeo Eiris. Euronext Vigeo Eiris World 120 Factsheet as of December-2018. 2018. Available online: http://www.vigeo-eiris.com/wp-content/uploads/2018/11/Indices_World120_122018.pdf (accessed on 22 August 2019).

83. Forum Ethibel Vigeo Eiris. Index Rule Book: Ethibel Sustainability Index (ESI) Family-Version 6.5, February 2017. 2017. Available online: http://www.vigeo-eiris.com/wp-content/uploads/2018/03/ESI-index-rule-book. pdf (accessed on 22 August 2019).

84. FTSE Group. FTSE ESG Rating: Integrating ESG into Investments and Stewardship. Available online: https://research.ftserussell.com/products/downloads/FTSE-ESG-Methodology-and-Usage-SummaryFull.pdf (accessed on 22 August 2019).

85. FTSE Russell. FTSE4Good Developed Index Factsheet-Data as at: 31 July 2019. 2019. Available online: https://research.ftserussell.com/Analytics/FactSheets/temp/f5d50ca1-9216-47c8-8a35-4d12952e5ff3.pdf (accessed on 22 August 2019).

86. FTSE Russell. Index Overview_FTSE4Good Index Series: Pioneering Global ESG Indexes. 2018. Available online: https://research.ftserussell.com/products/downloads/FTSE4Good-brochure.pdf (accessed on 22 August 2019).

87. FTSE Russell. Product Overview_ESG Ratings and Data Model: Integrating ESG into Investments. 2018. Available online: https://research.ftserussell.com/products/downloads/ESG-ratings-overview.pdf (accessed on 22 August 2019).

88. FTSE Russell. FTSE4Good-15-year Anniversary Report: Past, Present and Future of Sustainable Investment. 2016. Available online: https://www.eticanews.it/wp-content/uploads/2017/01/r3_160060_anniversary_ report_web1.pdf (accessed on 22 August 2019).

89. ISS-oekom Research. oekom Corporate Responsibility Review 2018: The Materiality and Impact of Sustainability Research. 2018. Available online: https://www.issgovernance.com/file/publications/cr-review2018-en.pdf (accessed on 22 August 2019).

90. ISS-oekom. Methodology: ISS-oekom Corporate Rating. 2018. Available online: https://www.issgovernance.com/file/products/ISS-oekom_Factsheet_Corporate_Rating_Methodology_E. pdf?elqTrackId=d4da29d079e641b2aa8c3a5d6f272844\&elq=ccaf4f847a5b4dc0afcee3f143e1dc04\&elqaid= 1456\&elqat=1\&elqCampaignId= (accessed on 22 August 2019).

91. MSCI Inc. MSCI World ESG Leaders Index Factsheet-31 July 2019. 2019. Available online: https://www.msci. com/documents/10199/db88cb95-3bf3-424c-b776-bfdcca67d460 (accessed on 22 August 2019).

92. MSCI Inc. Index Methodology: MSCI ESG Leaders Indexes Methodology, May 2018. 2018. Available online: https://www.msci.com/eqb/methodology/meth_docs/MSCI_ESG_Leaders_Methodology_May_2018. pdf (accessed on 22 August 2019). 
93. MSCI Inc. MSCI ESG Ratings Methodology-Executive Summary, April 2018. 2018. Available online: https://www.msci.com/documents/10199/123a2b2b-1395-4aa2-a121-ea14de6d708a (accessed on 22 August 2019).

94. MSCI Inc. MSCI ESG Leaders Indexes: A Simple and Transparent ESG Index Designed for Institutional Investors Seeking the Highest ESG Rated Companies. 2017. Available online: https://www.msci.com/documents/1296102/1362201/MSCI_ESGLeaders_Factsheet-May-2018.pdf/ 6d0c8724-105c-60d0-7c57-67a09ba0a3ce (accessed on 22 August 2019).

95. Reputation Institute (RI). Global CR RepTrak 100: Raising the Stakes on Corporate Responsibility-11 October 2018. 2018. Available online: https://ri.reputationinstitute.com/hubfs/_PDF/RepTrak/2018_Global_ CR_100.pdf (accessed on 22 August 2019).

96. RobecoSAM. The Sustainability Yearbook 2019. 2019. Available online: https://yearbook.robecosam.com/ fileadmin/Files/Documents/2019/The_Sustainability_Yearbook_2019.pdf (accessed on 22 August 2019).

97. RobecoSAM. SAM Corporate Sustainability Assessment 2019: Criterion Weights by SAM Industry-Updated as per 25 March 2019. 2019. Available online: https://assessments.robecosam.com/documents/SAM_CSA_ Weights_2019.pdf (accessed on 22 August 2019).

98. RobecoSAM. SAM 2019 Methodology Update: SAM Corporate Sustainability Assessment_April 2019. 2019. Available online: https://assessments.robecosam.com/documents/SAM_CSA_MethodologyChanges_2019. pdf (accessed on 22 August 2019).

99. RobecoSAM. DJSI 2018 Review Results: September 2018. 2018. Available online: https://www.robecosam. com/media/0/4/3/043cd016c8d1952fdd23ee4b2dac909d_review-presentation-2018_tcm1016-14658.pdf (accessed on 22 August 2019).

100. RobecoSAM. Measuring Intangibles: RobecoSAM's Corporate Sustainability Assessment Methodology. 2018. Available online: https://www.robecosam.com/media/d/0/1/d013178bf9bfae863cbea53a27584ac1_measuringintangibles-csa-methodology_tcm1011-15705.pdf (accessed on 22 August 2019).

101. RobecoSAM. 2018 RobecoSAM Corporate Sustainability Assessment-Annual Scoring \& Methodology Review. 2018. Available online: https:/www.robecosam.com/media/3/8/f/38fe11a7622afc00181ef19f865c2972_ csa-2018-annual-scoring-methodology-review_tcm1016-14369.pdf (accessed on 22 August 2019).

102. S\&P Dow Jones Indices LLC. Dow Jones Sustainability World Index Factsheet as of 31 July 2019. 2019. Available online: https://us.spindices.com/indices/equity/dow-jones-sustainability-world-index (accessed on 22 August 2019).

103. S\&P Dow Jones Indices LLC; RobecoSAM. Dow Jones Sustainability Indices Methodology—July 2019. 2019. Available online: https:/us.spindices.com/documents/methodologies/methodology-dj-sustainability-indices. pdf (accessed on 22 August 2019).

104. STOXX. STOXX Global ESG Leaders Index Developed Factsheet as of 31 July 2019. 2019. Available online: https://www.stoxx.com/index-details?symbol=SXWESGP (accessed on 22 August 2019).

105. STOXX. STOXX Global ESG Leaders Index Components Factsheet as of 21 August 2019. 2019. Available online: https://www.stoxx.com/index-details?symbol=SXWESGP (accessed on 22 August 2019).

106. STOXX. STOXX ESG Index Methodology Guide. August 2019. Available online: https://www.stoxx.com/ index-details?symbol=SXWESGP (accessed on 22 August 2019).

107. Sustainalytics. Sustainalytics ESG Risk Rating Summary Report-11 July 2019. 2019. Available online: https://www.sustainalytics.com/sustainable-finance/wp-content/uploads/2019/07/Barry_Callebaut_ AG_Risk-Ratings-Summary-Report_11072019.pdf (accessed on 22 August 2019).

108. Sustainalytics. ESG Ratings \& Research. 2019. Available online: https://www.sustainalytics.com/esg-ratings/ \#1530569112571-dc5cd200-dc38 (accessed on 22 August 2019).

109. Sustainalytics. Global Sustainability Leaders Index (GSLI) Factsheet as of 1 October 2012 to 31 August 2018. 2018. Available online: https://www.sustainalytics.com/global-sustainability-leaders-index/ (accessed on 22 August 2019).

110. Sustainalytics. The ESG Risk Ratings: Moving Up the Innovation Curve-12 September 2018. 2018. Available online: https://www.am-league.com/files/news/esgriskratings_white_paper_summary.pdf (accessed on 22 August 2019). 
111. Sustainalytics; Solactive. Guideline: The Global Sustainability Leaders Index-Version 1.0 dated 29 November 2017. 2017. Available online: https://www.solactive.com/wp-content/uploads/2018/01/Guideline-GSLI.pdf (accessed on 22 August 2019).

112. Vigeo Eiris. Ethibel Sustainability Index (ESI) Excellence Global Factsheet as of 2019_03. 2019. Available online: http://www.vigeo-eiris.com/wp-content/uploads/2019/04/ESI_GLOBAL_2019_03-IndexConstituentsList. pdf (accessed on 22 August 2019).

(c)

(C) 2020 by the authors. Licensee MDPI, Basel, Switzerland. This article is an open access article distributed under the terms and conditions of the Creative Commons Attribution (CC BY) license (http://creativecommons.org/licenses/by/4.0/). 